\title{
DISPUTING THROUGH AGENTS: COOPERATION AND CONFLICT BETWEEN LAWYERS IN LITIGATION
}

\author{
Ronald J. Gilson $\mathcal{E}^{2}$ Robert H. Mnookin*
}

\begin{abstract}
Most civil cases are settled before trial but not until years of legal wrangling have tied up the courts and run up large fees and expenses. Cases aren't settled sooner because lawyers, who benefit most from litigation, are in control-not the clients who pay the bill.
\end{abstract}

-Whitney North Seymour, $1992^{1}$

Discourage litigation. . . . As a peace-maker the lawyer has a superior opportunity of being a good man. There will still be business enough.

-Abraham Lincoln, $1850^{2}$

\section{INTRODUCTION}

Do lawyers facilitate dispute resolution or do they instead exacerbate conflict and pose a barrier to the efficient resolution of disputes? A distinctive characteristic of our formal mechanisms of conflict resolution is that clients carry on their disputes through lawyers. Yet, at a time when the role of lawyers in dispute resolution has captured not only public but political attention, ${ }^{3}$ social scientists have remained largely uninterested in

* Respectively, Charles J. Meyers Professor of Law and Business, Stanford University, and Marc and Eva Stern Professor of Law and Business, Columbia University; and Samuel Williston Professor of Law, Harvard University, and Chairman, Steering Committee, Harvard Program on Negotiation. The Kendyl K. Monroe Research Fund and the John M. Olin Program in Law and Economics, both at Stanford Law School, the Stanford Center on Conflict and Negotiation, the Columbia University School of Law, the Harvard Law School Faculty Summer Research Program, and the Harvard Program on Law and Economics, which is funded by the John M. Olin Foundation, provided research support for this paper, for which the authors are grateful. The authors also appreciate the helpful comments of Ian Ayres, Stephen Bundy, Rachel Croson, Robert Frank, Marc Galanter, Jeffrey Gordon, Pamela Karlan, Reinier Kraakman, Deborah Rhode, Thomas Schelling, William Simon, Stephen Sugerman and Robert Wilson; the participants at the Stanford Center on Conflict and Negotiation conference on New Theoretical Approaches to Conflict Resolution; the Law and Economics Workshops at Harvard Law School, Columbia University School of Law, the Stanford Faculty Workshop, and the Law, Economics and Organization Workshop at Yale Law School. Finally, we are grateful to George Lichter, Jill Thompson, Tracey George, Shuba Ghosh, and Sakris Jebejian for research assistance. A shorter version of this Article will appear as a chapter in Barriers to the Negotiated Resolution of Conflict (Kenneth Arrow et al. eds., W.W. Norton \& Co., forthcoming).

1. Whitney N. Seymour, Cheaper, Faster Civil Justice, N.Y. Times, Jan. 7, 1992, at A15.

2. Abraham Lincoln, Notes for a Law Lecture, in The Life and Writings of Abraham Lincoln 328, 329 (Philip V.D. Stern ed., 1940).

3. See President's Council on Competitiveness, Agenda for Civil Justice Reform in America (1991) (report from Quayle Commission); David Margolick, Address by Quayle on Justice Proposals Irks Bar Association, N.Y. Times, Aug. 14, 1991, at A1 (Vice-President Quayle complains that litigation explosion hampers competitiveness of U.S. industry). 
the influence of lawyers on the disputing process. This is not to say that academics have ignored the growth in civil litigation in the United States. ${ }^{4}$ Economists have developed an extensive literature that models one or another aspect of the litigation and settlement process. ${ }^{5}$ But the economic literature, with rare exceptions, shares a troublesome feature. Almost by convention, litigation is modeled as a two-person game between principals, ${ }^{6}$ thereby abstracting away the legal system's central institutional characteristic-litigation is carried out by agents. ${ }^{7}$

While any model must make concessions to tractability, this simplifying assumption is especially troublesome because lawyers have long been considered to have a special influence on how litigation is conducted, even if there has been no consensus on whether lawyers dampen or exacerbate conflict in litigation. ${ }^{8}$ Today, the dominant popular view is that

4. For accounts of the growth in civil litigation, see Marc Galanter, The Life and Times of the Big Six; or, The Federal Courts Since the Good Old Days, 1988 Wis. L. Rev. 921, 923-46; Marc Galanter \& Joel Rodgers, A Transformation of American Business Disputing? Some Preliminary Observations (Institute for Legal Studies Working Paper No. DPRP 10-3, 1991). For a popular account, see Walter K. Olson, The Litigation Explosion (1991).

5. For an excellent survey, see Robert D. Cooter \& Daniel L. Rubinfeld, Economic Analysis of Legal Disputes and Their Resolution, 27 J. Econ. Literature 1067 (1989).

6. See, e.g., id. at 1070.

7. This is a particularly curious feature because many of the contributors to the economics of litigation literature have also worked in the principal and agent field. There are, of course, exceptions. See, e.g., Stephen R.G. Jones, Have Your Lawyer Call My Lawyer: Bilateral Delegation in Bargaining Situations, $11 \mathrm{~J}$. Econ. Behav. \& Org. 159 (1989) (analyzing consequences on bargaining when both parties delegate authority to outside negotiators). Michael Katz considers more generally the impact on the outcome of the game of a principal delegating the game-playing role to an agent. See Michael L. Katz, Game-Playing Agents: Unobservable Contracts as Precommitments, 22 Rand J. Econ. 307 (1991). More attention has been directed at the influence of fee arrangements on the conduct of litigation. See, e.g., John C. Coffee, Jr., Understanding the Plaintiff's Attorney: The Implications of Economic Theory for Private Enforcement of Law Through Class and Derivative Actions, 86 Colum. L. Rev. 669 (1986); Terry Thomason, Are Attorneys Paid What They're Worth? Contingent Fees and the Settlement Process, 20 J. Legal Stud. 187 (1991).

For an interesting collection of essays on principal-agent issues generally, see Principals and Agents: The Structure of Business (John W. Pratt \& Richard J. Zeckhauser eds., 1985).

Of special interest are empirical studies said to demonstrate that, in disputes when the use of a lawyer is optional (that is, plaintiffs and defendants can plausibly choose to assert or defend the claim themselves), the decision whether to retain counsel at all poses a prisoner's dilemma. See Richard N. Block \& Jack Stieber, The Impact of Attorneys and Arbitrators on Arbitration Awards, 40 Indus. \& Lab. Rel. Rev. 543 (1987); Orley Ashenfelter \& David Bloom, Lawyers as Agents of the Devil in a Prisoner's Dilemma Game 11-19 (National Bureau of Economic Research Working Paper No. 4447, 1993). We consider these studies infra note 42.

8. See generally Gwynn Davis, Partisans and Mediators: The Resolution of Divorce Disputes 85-126 (1988) (examining positive and negative impressions of British solicitors in divorce negotiation); John S. Murray et al., Processes of Dispute Resolution: The Role of Lawyers 52, 76-80 (1989) (citing attorney "self interest" in "substantial fees" and threat to attorney's "exclusive control" over dispute resolution as causing attorney indifference to 
lawyers magnify the inherent divisiveness of dispute resolution. ${ }^{9}$ According to this vision, litigators rarely cooperate to resolve disputes efficiently. Instead, shielded by a professional ideology that is said to require zealous advocacy, they endlessly and wastefully fight in ways that enrich themselves but rarely advantage the clients. ${ }^{10}$

Many within the legal profession share this pessimistic view, as is suggested by the quoted comment of Whitney North Seymour, former United States Attorney for the Southern District of New York and President of the New York Bar Association. ${ }^{11}$ Claims that the conduct of litigation has become uncivil and unprofessional, and that lawyers' conduct has deteriorated in ways that increase the contentiousness of civil litigation, are now standard fare for lawyer convocations. ${ }^{12}$ Interestingly, the anguish about the current state of affairs is not over the behavior of a few disreputable lawyers who abuse litigation practices in ways that respectable lawyers from white-shoe firms would not. Rather, the concern

ADR); Gerald R. Williams, Legal Negotiation and Settlement 147-54 (1983) (comparing competitive and cooperative strategies of negotiation); Leonard L. Riskin, Mediation and Lawyers, 43 Ohio St. L.J. 29, 43-48, 57-59 (1982). For sources criticizing the legal profession for unnecessarily intensifying hostility between disputants, see, e.g., Riane T. Eisler, Dissolution: No-Fault Divorce, Marriage, and the Future of Women 40 (1977) (discussing lawyering strategies that "exaggerate, rather than resolve . . . emotional tensions" in divorce disputes); Marvin E. Frankel, Partisan Justice 36, 114 (1980) (showing how overly zealous lawyers "exacerbate and prolong" conflict); Derek C. Bok, A Flawed System of Law Practice and Training, 33 J. Legal Educ. 570, 582-83 (1983) (criticizing legal education for preparing students for "legal combat" rather than reconciliation and cooperation); Michael J. Kaufman, The Role of Lawyers in Civil Litigation: Obstructors Rather than Facilitators of Justice, 77 Ill. B.J. 202, 203-08 (1988) (arguing attorneys engage in practices that obstruct resolution); Carrie Menkel-Meadow, Pursuing Settlement in an Adversary Culture: A Tale of Innovation Co-opted or "The Law of ADR," 19 Fla. St. U. L. Rev. 1 (1991). For a discussion of how lawyers can facilitate dispute resolution, see, e.g., Melvin A. Eisenberg, Private Ordering Through Negotiation: Dispute-Settlement and Rulemaking, 89 Harv. L. Rev. 637, 660, 662 (1976); see also Carrie Menkel-Meadow, Toward Another View of Legal Negotiation: The Structure of Problem Solving, 31 UCLA L. Rev. 754, 775-89, 817-29 (1984) (criticizing the adversarial approach to legal negotiation and suggesting an alternative "problem-solving" model).

9. See, e.g., The Tenth Annual Judicial Conference of the United States Court of Appeals for the Federal Circuit, 146 F.R.D. 205, 216-32 (1992) (discussing "the Rambo Litigator"); Robert H. Aronson, Introduction: The Bounds of Advocacy, $9 \mathrm{~J}$. Am. Acad. Matrim. Law. 41, 52-54 (1992); Eugene A. Cook, Professionalism and the Practice of Law, 23 Tex. Tech L. Rev. 955, 969-82 (1992); Thomas M. Reavley, Rambo Litigators: Pitting Aggressive Tactics Against Legal Ethics, 17 Pepp. L. Rev. 637, 637 (1990); Leonard M. Ring, The Incivility Crisis, Trial, Aug. 1993, at 78, 78-80; Helen W. Nies, Rambo Lawyering: The Need for Civility in Civil Litigation, 32 IDEA 1, 1-2 (1991).

10. See, e.g., infra note 25 on discovery abuse. According to a recent survey, approximately $94 \%$ of lawyers who perceived a civility problem identified discovery as the main breeding ground for conflict. See Interim Report of the Committee on Civility of the Seventh Federal Judicial Circuit, 143 F.R.D. 371, 380 (1991).

11. See Seymour, supra note 1, at A15.

12. In 1989, for example, the focus of the Ninth Circuit Judicial Conference was on the decline of "professionalism" in the conduct of litigation. See 1989 Ninth Circuit Judicial Conference: Partners in the Process 3-28 (1989). 
is that, like Pogo, big-city commercial litigators have met the enemy in themselves-litigators from the great national law firms are now perceived as very much a part of the problem. ${ }^{13}$

Purveyor of needless conflict need not be the only vision of the lawyer's role in litigation. Over a century ago, Abraham Lincoln suggested that lawyers can play an extraordinarily constructive role in disputes-as peacemakers who facilitate efficient and fair resolution of conflict when their clients could not do so for themselves. ${ }^{14}$ From this perspective, a central characteristic of the formal legal system-that clients carry on their dispute through lawyers who are their agents-has the potential for damping rather than exacerbating the conflictual character of litigation. In this Article we offer a conceptual foundation for this alternative perspective-a foundation that rests on the idea that lawyers may allow clients to cooperate in circumstances when their clients could not do so on their own. We construct this foundation using basic notions drawn from game theory and agency theory.

We begin by using the prisoner's dilemma as a heuristic to understand better the circumstances of disputants locked in a legal conflict in an abstract world in which there are no lawyers-only the parties themselves and a judge. In Part I, we describe a litigation game in which each disputant faces a single choice: she can either cooperate by volunteering all relevant information to the other side or defect by using the discovery process in an adversarial manner to hide unfavorable information. We analyze litigation initially in the form of this one-round, two-person prisoner's dilemma, in which the inability of parties to commit effectively to cooperation results in dominant strategies that yield suboptimal results. Because a single lawsuit has a number of strategic interactions, we then analyze litigation as a finite number of repeated games, each of which is structured as a prisoner's dilemma. Our primary message in Part I is that in many legal conflicts each disputant may feel compelled to make a contentious move in order to avoid being exploited by, and to take advantage of any weakness in, the other side. Nevertheless, the net result of contentious moves by both may be an outcome that is less efficient than if the disputants had cooperated.

In Part II, we explore the role that lawyers might play in overcoming the prisoner's dilemma. Our analysis in this Part, unlike most game theoretic models of the litigation process, acknowledges the central institutional characteristic of the legal system-litigation is carried out by lawyers on behalf of their clients. We suggest that, in contrast to clients

13. Responding to complaints of unethically conflictual advocacy on behalf of its clients, the chairman of Sullivan \& Cromwell, one of the oldest and most prestigious New York firms, was reported to have said that "[ $\mathrm{t}]$ he complaints show Sullivan \& Cromwell fights tough . . . and 'clients like a law firm that's aggressive.'” Patricia B. Gray, Legal Nightmare: Multiple Allegations of Impropriety Beset Sullivan \& Cromwell, Wall St. J., Aug. 3, 1987, at A1.

14. See Lincoln, supra note 2 , at $328-30$. 
who are unlikely to litigate against one another ever again, lawyers are repeat players who have the opportunity to establish reputations. At the core of our story is the potential for disputing parties to avoid the prisoner's dilemma inherent in much litigation by selecting cooperative lawyers whose reputations credibly commit each party to a cooperative strategy.

At this point, we introduce a dialectical tension between game theory and agency theory. On the one hand, we suggest that the possibility for commitment to cooperation exists because the incentives for a cooperative lawyer, who is a repeat player concerned with maintaining her reputation over time, differ from those of her client, who as a one-shot litigant may be tempted to defect. On the other hand, we suggest that because the interests of the client (as principal) and the interests of her lawyer (as agent) diverge in some respects, cooperation may be undermined in two very different ways. One danger is that the agents may "collude" to exacerbate conflict when that behavior serves their own interests. Alternatively, a principal may persuade a previously cooperative agent to defect in order to increase the principal's payoff.

We expose these dangers and the difficulties of establishing and maintaining an equilibrium in the market for cooperative lawyers first by exploring the problem in a world in which all lawyers are sole practitioners. Next, we examine whether law firms might be more effective repositories of reputation than individual lawyers. Through this analysis we show that the firm can ameliorate some principal-agent conflicts that may undermine cooperation. But, like the introduction of individual lawyers to the basic prisoner's dilemma game, the introduction of law firms adds a new level of agency conflict, now between the firm and the individual lawyers who compose it, that has the potential of undermining the ability of lawyers to reduce conflict in litigation.

Parts III and IV use this framework to explore the contemporary litigation scene from both a positive and normative orientation. Part III draws on our analysis to help understand the actual distribution of cooperation across different practice settings. After using our framework to analyze commercial litigation (where the widespread perception is that commercial litigators have become more adversarial) and matrimonial practice (where we describe cooperative patterns among some elite family law specialists in California), we offer some generalizations concerning those institutional features that are conducive to cooperation. These features include the size of the legal market, the incentives given to lawyers in that market, the complexity of the legal practice, and the nature of the legal culture. Finally, in Part IV we suggest strategies for increasing the level of cooperation in litigation. These strategies involve possible changes in codes of professional conduct, law firm structure, and the role of professional associations. 


\section{Litigation as a Prisoner's Dilemma}

The prisoner's dilemma ${ }^{15}$ provides a useful heuristic to illuminate a common characteristic of dispute settlement through litigation. In many disputes, each litigant may feel compelled to make a contentious move either to exploit, or to avoid exploitation by, the other side. Yet, the combination of contentious moves by both results in a less efficient outcome than if the litigants had been able to cooperate.

In this Part we first describe a litigation game with all the required characteristics of a one-round prisoner's dilemma, so as to expose this tension inherent in many legal disputes. Next, we analyze the assumptions underlying a prisoner's dilemma to expose both the opportunities and limits of using it as a heuristic for the litigation process. Finally, we complicate the analysis by drawing on research that explores the multiround prisoner's dilemma. We treat a single lawsuit as analogous to the same players playing a finite number of games, each round of which is structured as a prisoner's dilemma.

\section{A. The Litigation Game: A One-Round Prisoner's Dilemma}

Consider the following "litigation game," a highly abstracted model of litigation possessing the attributes of a one-round prisoner's dilemma. Able and Baker dispute the proper division of $\$ 100$ according to some legal standard. For the moment, assume that litigation does not involve lawyers, but only the two parties and a judge. Each party holds information not known by the other side. Some of this information is favorable and some of it is unfavorable. Before the judge decides the case, there is a one-stage simultaneous disclosure process in which each party hands to the judge and the opposing party a sealed envelope containing information. Only two moves are possible, and neither player can know in advance what the other will do. One move is cooperation: a player voluntarily (and at no cost to the other side) discloses to the other side and to the judge all material information in her possession. The second option, defection, involves the adversarial use of the disclosure process to

15. There is a rich literature on the prisoner's dilemma, which serves to illustrate the divergence between individual and collective rationality. The game, with its characteristic payoff structure, was devised in 1950 by two RAND researchers, Merrill Flood and Melvin Dresher. See William Poundstone, Prisoner's Dilemma 101-21 (1992). Albert W. Tucker is given credit for having coined the term "prisoner's dilemma," and for devising the classic version of the game in which two isolated suspects accused of a joint crime must each independently decide whether to confess in circumstances when the punishment for each depends on the actions of both. See id. at 116-18; Anatol Rapoport, Prisoner's Dilemma, in The New Palgrave: Game Theory 199, 199 (John Eatwell et al. eds., 1989). Useful introductions to game theory in general, and the prisoner's dilemma in particular, are found in David M. Kreps, Game Theory and Economic Modelling (1990); Roger B. Myerson, Game Theory: Analysis of Conflict 1-5, 97-98 (1991); Eric Rasmusen, Games and Information: An Introduction to Game Theory (1989). For a review of the early social psychology experimentation literature, see Jeffrey Z. Rubin \& Bert R. Brown, The Social Psychology of Bargaining and Negotiation 19-39 (1975). 
hide unfavorable information. As a consequence, the other side must spend $\$ 15$ to force disclosure of some but not all of the information withheld. After the envelope exchange and the "purchase" of some of the withheld information, the judge resolves the dispute based on the information disclosed.

With the payoff structure indicated by the following matrix, this game poses a prisoner's dilemma. If both players cooperate, there are no discovery expenses for either side and we will assume the judge awards $\$ 50$ to Able and $\$ 50$ to Baker. If both players defect, each must spend $\$ 15$ to pry out some but not all of the unfavorable information possessed by the other side. Although the judge lacks complete information, we assume that she divides the $\$ 100$ in the same ratio; the net recovery to the parties is now $\$ 35$ to Able and $\$ 35$ to Baker. The third scenario, in which one player defects while the other cooperates, provides the defector with a higher payoff ( $\$ 70)$ and hurts the "sucker" in two ways. First, because the cooperating player has disclosed all of its unfavorable information while the defecting party has only disclosed some of the information unfavorable to it, the Judge awards the sucker a gross recovery of only $\$ 30$. Second, the sucker has spent $\$ 15$ to get less than all of the information unfavorable to the other side before the judge (without which his recovery would be even lower). Thus, the sucker's net recovery is only $\$ 15$.

\section{PAYOFf Matrix}

\begin{tabular}{|c|c|c|c|}
\hline & \multicolumn{2}{|c|}{ Player One } \\
\hline & & Cooperate & Defect \\
\hline \multirow{2}{*}{$\begin{array}{l}\text { Player } \\
\text { Two }\end{array}$} & Cooperate & $50 / 50$ & $15 / 70$ \\
\hline & Defect & $70 / 15$ & $35 / 35$ \\
\hline
\end{tabular}

In this litigation game, Able's best response to whatever strategy Baker chooses is to defect. In other words, defection is Able's dominant strategy. ${ }^{16}$ The same, of course, is true for Baker. Defect-Defect, therefore, is a "dominant strategy equilibrium," 17 even though this result guarantees each party only $\$ 35$, rather than the $\$ 50$ produced by a strategy of mutual cooperation. If there is no way for the disputants to bind each other to make a cooperative move, rational actors end up with less than "fools" who simply cooperate. 27-30.

16. For a discussion of dominance in game theory, see Rasmusen, supra note 15 , at

17. Id. at 28-29. 


\section{B. Is the Prisoner's Dilemma an Appropriate Model for Litigation?}

To what extent does the prisoner's dilemma represent an appropriate, albeit highly simplified, model of the litigation process? Focus first on the payoff structure. In a prisoner's dilemma, the best payoff for a player occurs when that player defects and the other player cooperates. The worst payoff results when a player cooperates while the other player defects. The other two outcomes fall between these extremes, with the reward for mutual cooperation better than the payoff for mutual defection. This means that a prisoner's dilemma cannot be a zero sum or purely distributive game: the total combined payoff from mutual cooperation must exceed the total combined payoff from mutual defection. Indeed, in a symmetric prisoner's dilemma, each player's payoff from mutual cooperation must be greater than each player's payoff from mutual defection.

How realistic is it to assume that in litigation the payoff structure takes this form? In many disputes, the assumption that mutual cooperation might benefit both sides seems entirely plausible. Mutual cooperation involves lower total litigation costs than mutual defection. Moreover, when parties share information, reveal their true underlying interests, and engage in collaborative problem-solving, they may sometimes develop new options that "create value" or "expand the pie" for both disputants in comparison to the result flowing from mutual defection. ${ }^{18}$ Both parties may sometimes gain from a negotiated resolution that takes a form a judge could not impose. For example, both parties may prefer exchanging a property that the plaintiff values more highly than the defendant over a judicially determined damage award. It also seems plausible that the best and worst individual outcomes will occur when one party cooperates and the other does not. In many disputes, because of the adversarial nature of litigation, cooperative moves by one litigant, if not reciprocated by the other, can lead to exploitation and something akin to a sucker's payoff. Unbalanced discovery, where only one side discloses unfavorable information, yields this result.

Not every legal dispute involves the sort of payoff structure required by the prisoner's dilemma, and, as we suggest later, this has important implications. ${ }^{19}$ In some disputes the very best payoff for one or both players occurs when both players cooperate. ${ }^{20}$ In other cases, mutual defec-

18. Cf. David A. Lax \& James K. Sebenius, The Manager as Negotiator: Bargaining for Cooperation and Competitive Gain 29-32, 88-116 (1986) (illustrating how cooperation may "create value" in the negotiation context).

19. See infra text accompanying notes $68-77$.

20. This is true of the "Coordination Game" or the "Assurance Game" described in Amartya K. Sen, A Game-Theoretic Analysis of Theories of Collectivism in Allocation, in Growth and Choice: Essays in Honour of U.N. Ghosal 1, 3-6 (Tapas Majumdar ed., 1969). In these games if one player cooperates, the other player also wants to cooperate, but if one player defects the other player would also prefer to defect. See Rasmusen, supra note 15 , at 35 . In other words, if you assure me that you'll cooperate, I'll cooperate. 
tion may yield the best payoff for a defendant interested in delay because interest earned by putting off the damage payment may exceed any differential in transaction costs. This suggests the importance of exploring in particular legal contexts whether the payoff assumptions for the prisoner's dilemma are, in fact, appropriate.

The rules of the game ${ }^{21}$ for a prisoner's dilemma also require that each player remains ignorant of what the other player will do before making a move: enforceable commitments or contracts are not possible and thus the parties cannot credibly bind themselves to cooperate. ${ }^{22}$ At first glance, this restrictive assumption seems entirely inappropriate. Disputants in litigation can enter into enforceable agreements with respect to future conduct. The prisoner's dilemma disappears if the parties can, at reasonable cost, spell out the terms of an enforceable agreement to cooperate in the litigation, and thereby bind each other to exchange all relevant information so as to decrease litigation costs.

The problem is that in many cases, particularly complex ones, the parties may not be able to specify fully the terms of such an agreement in advance. ${ }^{23}$ Agreements with respect to certain aspects of litigation-for example, limiting the number of depositions, or adopting a particular discovery schedule - may be easy to write and enforce, but it may be very difficult or expensive to specify fully a contract to "conduct a lawsuit cooperatively" or "to disclose all material information." Moreover, even if the terms can be specified, it may be very difficult to determine whether a defection has occurred. Even where a breach of such a contract is observ-

21. Game theory requires that the rules of the game be specified, and include descriptions of the players, possible actions and strategies, information, order of play, and payoffs. See Rasmusen, supra note 15, at 22.

22. As Axelrod describes:

There is no mechanism available to the players to make enforceable threats or commitments. ... Since the players cannot commit themselves to a particular strategy, each must take into account all possible strategies that might be used by the other player. Moreover the players have all possible strategies available to themselves.

Robert M. Axelrod, The Evolution of Cooperation 11 (1984).

23. The idea that there are often "incomplete contracts" is, of course, a central tenet of transaction cost economics.

Uncertainty about the conditions that will prevail when a contract is being executed together with complexity of the task make it impossible or at least uneconomical to determine in advance what should be done in every possible contingency, so the contract that is written will generally be less determinative than in a simpler setting.

Paul Milgrom \& John Roberts, Economics, Organization and Management 32 (1992); see also id. at 129-40; Oliver E. Williamson, The Economic Institutions of Capitalism: Firms, Markets, Relational Contracting 178 (1985) (noting that complex contracts are "invariably incomplete" because of unforseen contingencies and incomplete knowledge prior to contract execution). 
able by the parties, a violation may be difficult to verify to a judge, thus making enforcement problematic. ${ }^{24}$

Discovery disputes in contentious cases reveal the severity of these problems. ${ }^{25}$ If one party claims that the other party has breached an agreement by engaging in abusive discovery practices, a judge often faces substantial evidentiary difficulties. Typically, the judge knows little about the information available to either the responding or the requesting party. ${ }^{26}$

If the responding party were to produce fully the information sought and display it to the judge, the responding party would already have incurred all the costs that [she] was trying to avoid. [In] the absence of such production, the responding party has some leeway with which to exaggerate the burden of response, and a wise judge will thus to some extent discount the protestations of that responding party.

The requesting party provides no more reliable guidance, as that party possesses the incentive to exaggerate, in a complimentary fashion, the ease with which the responding party can produce the information. ${ }^{27}$

This problem also suggests why a judge may be no more able to ensure cooperation by enforcing general rules of procedure than by enforc-

24. For the distinction between a defection being observable and it being verifiable, see David M. Kreps, Corporate Culture and Economic Theory, in Perspectives on Positive Political Economy 90, 110, 112 (James E. Alt \& Kenneth A. Shepsle eds., 1990).

25. For analysis of abusive discovery practices, see, e.g., Wayne D. Brazil, The Adversary Character of Civil Discovery: A Critique and Proposals for Change, 31 Vand. L. Rev. 1295, 1315-31 (1978) [hereinafter Brazil, The Adversary Character of Civil Discovery]; Wayne D. Brazil, Civil Discovery: Lawyers' Views of Its Effectiveness, Its Principal Problems and Abuses, 1980 Am. B. Found. Res. J. 789, 824-59; Stanley J. Levy, Discovery-Use, and Abuse, Myth and Reality, 17 Forum 465, 468 (1981); William W Schwarzer, Slaying the Monsters of Cost and Delay: Would Disclosure Be More Effective Than Discovery?, 74 Judicature 178, 178-79 (1991); Note, Discovery Abuse Under the Federal Rules: Causes and Cures, 92 Yale L.J. 352, 353-58 (1982); Philip H. Corboy, Discovery Wars and the Trial Lawyer, Speech at the American Bar Association Annual Convention 11-12 (Aug. 4, 1990) (on file with the Columbia Law Review).

26. As Judge Easterbrook has stated:

Judges can do little about impositional discovery when parties control the legal claims to be presented and conduct the discovery themselves .... The judicial officer always knows less than the parties .... A magistrate supervising discovery does not-cannot-know the expected productivity of a given request, because the nature of the requester's claim and the content of the files (or head) of the adverse party are unknown. Judicial officers cannot measure the costs and benefits to the requester and so cannot isolate impositional requests. . . . We cannot prevent what we cannot detect; we cannot detect what we cannot define; we cannot define "abusive" discovery except in theory, because in practice we lack essential information.

Frank H. Easterbrook, Comment, Discovery as Abuse, 69 B.U. L. Rev. 635, 638-39 (1989) (footnote omitted).

27. John K. Setear, The Barrister and the Bomb: The Dynamics of Cooperation, Nuclear Deterrence, and Discovery Abuse, 69 B.U. L. Rev. 569, 593 (1989). 
ing a general contract between the parties. A vague or nonspecific rule that requires litigators to "conduct a lawsuit cooperatively" or "to disclose voluntarily all material information" is easy to write, but poses potentially severe enforcement difficulties. In our game, for example, if the judge could identify defection, then the judge could punish defection severely enough so as to deter it from ever occurring. Relying on the judge, the parties could then avoid the prisoner's dilemma. Unfortunately, breaches of general rules of procedure-e.g., "do not engage in burdensome discovery"-are no easier to verify than are breaches of a contract of similar specificity. In other words, a judge may have grave difficulty verifying defection even when both parties know it has occurred..$^{28}$

28. Suggestive in this regard is the controversy concerning the recent changes to Federal Rule 26, which went into effect December 1, 1993. Among other things, the amendments impose affirmative (rather than responsive) disclosure requirements concerning "documents . . that are relevant to disputed facts alleged with particularity." Fed. R. Civ. P. 26(a) (1) (B). Justice Scalia, joined by Justices Thomas and Souter, dissented from the "radical alteration" of the proposed change to Rule 26, suggesting that "[i]t will likely increase the discovery burdens on district judges, as parties litigate about what is 'relevant' to 'disputed facts,' whether those facts have been alleged with sufficient particularity, whether the opposing side has adequately disclosed required information, and whether it has fulfilled its continuing obligation to supplement the initial disclosure." Amendments to the Fed. R. Civ. P., 146 F.R.D. 401, 510-12 (1993) (Scalia, J., dissenting).

Echoing Justice Scalia, critics of the proposed rule have suggested that general disclosure obligations, not geared to specific sorts of cases, will increase the contentiousness of the pretrial discovery process but will not increase the level of cooperation among attorneys:

The fundamental flaw in the Committee's proposal is that it attempts to define a disclosure standard that will apply to all types of civil litigation, from simple collection cases to patent, securities, and antitrust claims. The only way to frame a standard which covers such a diverse range of cases is to use the broadest, most non-specific terms, such as "bears significantly on any claim or defense" or "relevant to the disputed facts." As demonstrated by the litigious history of the "relevance" standard under current Rule 26, however, the result of this vagueness will inevitably be confusion, disagreement, cost, and delay. . . .

The second flaw in the automatic disclosure process is that it is based on the Committee's somewhat puzzling belief that the disclosure requirement would return a level of professionalism and harmony to the discovery process. . . . [V] arious members stated that the requirement would change the atmosphere in litigation to create a more cooperative attitude and indeed "change the culture of adversariness."

This predicted benefit of automatic disclosure is particularly problematic because it will not replace the current discovery process, which the Advisory Committee found to be overly contentious. Rather, the new rule simply adds a new layer of disclosure, under a new standard which will create its own procedural problems. ... The automatic disclosure standard thus will provide little more than an initial offering of information, succeeded by the traditional forms of discovery and the associated problems that were supposedly to be avoided.

Griffin B. Bell et al., Automatic Disclosure in Discovery-The Rush to Reform, $27 \mathrm{Ga}$. L. Rev. 1, 39-40 (1992) (footnote omitted). For an account of negative public reaction to the proposed amendments see id. at 28-32. 
In sum, the payoff structure specified for a prisoner's dilemma seems appropriate for many disputes. Moreover, verification problems make the adequate enforcement of binding general commitments to cooperate in litigation (whether imposed by contract or rule) highly problematic. Therefore, despite its restrictive assumptions about payoffs and blind action, the prisoner's dilemma game is a powerful heuristic for understanding the barriers to cooperation in litigation.

\section{Litigation as a Multi-Round Prisoner's Dilemma Game}

At first glance, litigation between principals who are unlikely to sue each other again appears to be a one-round game. However, one can view a single lawsuit as consisting of a number of strategic encounters: each discovery request, the scheduling of depositions, and each motion might be seen as a separate game between the same parties. If each of these many tactical encounters during a lawsuit has the structure of a prisoner's dilemma, does the fact that the same parties play each other on multiple occasions over the course of a single lawsuit provide an opportunity for cooperation that is not available to players in a one-round game?

The answer seems to be no, although the explanation is more complicated than it once appeared. There is a rich theoretical literature analyzing "repeated games," which explores how rational players might behave in the context of a long-term relationship. ${ }^{29}$ Duncan Luce and Howard Raiffa demonstrated some time ago that, so long as the prisoner's dilemma game is played a known finite number of times, rational players still have no incentive to cooperate. The reasoning is straightforward. In the last round, both players recognize that there is no incentive to cooperate because the final game is identical to the one-round game described above. ${ }^{30}$ Now consider the next-to-last round. Because the players know that both will defect in the last round, the next-to-last round is no different from the last. Reasoning backwards round by round, the multi-round game unravels all the way back to the first round. ${ }^{31}$

More recent research, however, suggests that cooperative behavior can develop in a multi-round prisoner's dilemma under certain conditions. Suppose that, instead of a known finite number of rounds, there is only a known probability that the game will end before infinite time has passed. If there is a high enough probability in each round that the parties will play an additional round, the prospect of future dealings can induce cooperation, depending upon the payoff function. ${ }^{32}$ Robert

29. See Myerson, supra note 15, at 308-10, 337-42; Jean-François Mertens, Repeated Games, in The New Palgrave: Game Theory, supra note 15, at 205.

30. See R. Duncan Luce \& Howard Raiffa, Games and Decisions: Introduction and Critical Survey 97-102 (1957).

31. See id.

32. In an infinitely repeated prisoner's dilemma game, it might be thought that eternal cooperation would be the equilibrium. The Folk Theorem demonstrates, however, 
Axelrod studied the question of what would be a good strategy if players were confronted with an iterated prisoner's dilemma. Axelrod invited game theorists to participate in a computer tournament in which each submitted a strategy that was paired off with every other submission. "Amazingly enough, the winner was the simplest of all strategies submitted. This was TIT FOR TAT, the strategy which cooperates on the first move and then does whatever the other player did on the previous move." 33 Other theoretical research suggests that cooperation may be sustained even in games of a known number of rounds, provided the number of rounds is large enough and the players believe there are at least a few players in the population who will always play cooperatively. ${ }^{34}$

Together, this work indicates that there may be circumstances under which the parties can escape the prisoner's dilemma if there are significantly high prospects that they will have a large number of future dealings with each other and that they care enough about the outcomes of those future dealings. Unfortunately, the conditions necessary for cooperation in the course of a single lawsuit, even when broken down into a series of subgames, are sufficiently rigorous that the one-shot prisoner's dilemma remains the correct heuristic with which to explore the potential for lawyers to facilitate cooperation.

First, unlike the multi-round games considered in the theoretical literature, the aggregate payoff to the subgames of the decomposed litigation remains reasonably fixed. Also, the number of subgames in litigation, while perhaps unspecifiable ex ante, has predictable finite limits. To be more precise, because players can locate with reasonable precision the final round of a lawsuit, unraveling may begin. ${ }^{35}$ In this sense, a lawsuit is unlike a repeated game in which there is simply a finite probability that the game may end after any given round. Finally, the strategies that induce cooperation in repeated games require that each party know after each round whether an opponent cooperated or defected. In litigation, where even cooperative behavior occurs in the context of a competitive environment, the risk of misunderstanding an opponent's move is significant. In the prisoner's dilemma, each player has only two basic moves:

that there are a multiplicity of equilibrium strategies. See Rasmusen, supra note 15 , at 91-94.

33. Axelrod, supra note 22 , at 20 . When the tournament was replayed after the participants were advised of the initial winner and allowed to alter their strategies in light of that outcome, tit-for-tat won again. See id. The effectiveness of tit-for-tat depends, however, on the pool of other players and their strategies. See Rasmusen, supra note 15, at 120.

34. See David M. Kreps et al., Rational Cooperation in the Finitely Repeated Prisoners' Dilemma, 27 J. Econ. Theory 245 (1982); Paul Milgrom \& John Roberts, Predation, Reputation, and Entry Deterrence, $27 \mathrm{~J}$. Econ. Theory 280 (1982).

35. The Folk Theorem demonstrates that as the discount rate used to discount future payments increases, the present gain from defecting is weighed more heavily and future gains discounted more heavily. It turns out that with a high enough discount rate, a repeated game "almost returns to being one-shot." Rasmusen, supra note 15, at 92. 
cooperation or defection. In litigation, there are many gray tones between the black and white of these two pure moves. The opposing party often takes an action that must be evaluated by degree: Was the action too competitive and therefore a defection? Mistakes and misunderstandings can lead to conflictual outcomes even when both parties seek to follow a cooperative strategy. ${ }^{36}$

\section{The Role Lawyers Might Play in Overcoming the Prisoner's Dilemma}

We are now ready to introduce individual lawyers into the clients' prisoner's dilemma model of litigation. Assuming the particular litigation game has the payoff structure of a prisoner's dilemma, each client would prefer mutual cooperation to mutual defection. However, each lacks the means credibly to commit to her good intentions. In this Part, we show how disputing through lawyers may provide a means to make such a commitment: Lawyers, acting as agents, have the potential to solve the game theoretic problem of mutual defection. We then consider the first level of the game theory-agency theory dialectic: how use of an agent to precommit to cooperate creates its own set of agency problems. Initially we consider a world of sole practitioners-all lawyers practice alone. Later we consider representation by firms of lawyers.

\section{A. The Pre-Litigation Game: Choosing Lawyers}

Assume that both clients must litigate through a lawyer (an assumption that, for a change, is descriptively accurate). Further suppose that there exists a class of sole practitioners who have reputations for cooperation which assure that, once retained, they will conduct the litigation in a cooperative fashion. ${ }^{37}$ Three final assumptions define our "pre-litigation game." First, clients disclose their choice of lawyer-and thus, whether they have chosen a cooperative lawyer-prior to the beginning of the litigation game. Second, if one client chooses a cooperative lawyer and her opponent does not, the client choosing a cooperative lawyer can change her mind without cost before the litigation game begins. Third, after the litigation game begins, clients cannot change lawyers.

Under these assumptions, disputing through lawyers provides an escape from the prisoner's dilemma. As we have defined the pre-litigation game, each client's dominant strategy is to choose a cooperative lawyer because the choice of a cooperative lawyer binds each client to a coopera-

36. Even if both players are following a strategy of tit-for-tat, the game can deteriorate into alternating defections if the parties mistake cooperation for defection with sufficient frequency. See Jonathan Bendor et al., When in Doubt . . . Cooperation in a Noisy Prisoner's Dilemma, 35 J. Conflict Resol. 691, 691-706 (1991); infra Part III.C.3 (discussing effects of complexity on increasing the likelihood of mistaken defections).

37. We defer for now the quite central question of how (and why) such lawyers established their reputations. We return to this question in Part II.B after developing the notion that cooperative lawyers can help solve their clients' prisoner's dilemma. 
tive strategy. ${ }^{38}$ If client $A$ chooses a cooperative lawyer and client $B$ also chooses a cooperative lawyer, both clients receive the higher cooperative payoff. Alternatively, if client $B$ does not choose a cooperative lawyer, client $A$ is no worse off having initially chosen to cooperate. In that event, client $A$ replaces her cooperative lawyer with a gladiator and is in the same position as if she had chosen a gladiator in the first instance. Thus, her dominant strategy is to choose a cooperative lawyer and to switch if her opponent does not adopt a parallel strategy. Of course, client $B$ confronts the same choices and has the same dominant strategy. The result is a cooperative equilibrium because the introduction of lawyers has transformed the prisoner's dilemma payoff structure into a game in which the only choices are mutual cooperation or mutual defection. Mutual cooperation obviously has the higher payoff for each party.

This is the easy part. Designing a game in which the players can credibly commit is not difficult if one assumes the availability of commitment techniques. ${ }^{39}$ What makes the game interesting from a policy perspective is the extent to which its assumptions are consistent with institutional patterns. This consistency is what interests us about lawyers as sources of credible commitments: We believe the assumptions that define the pre-litigation game are roughly consistent with the way litigation occurs.

In the pre-litigation game, we first required clients to disclose their choice of lawyer before the game began. In real litigation, plaintiffs must typically disclose their choice of lawyer at the outset of litigation: the lawyer's name is, quite literally, the first thing that appears on the complaint. Similarly, the defendant must have a lawyer to respond to the complaint, and even to request an extension of the time in which to file an answer to the complaint. Again, this discloses the identity of the lawyer chosen.

We next assumed that a plaintiff choosing a cooperative lawyer could costlessly switch to a gladiator upon learning that her opponent had chosen a gladiator. In the real world, there are costs in switching lawyers, but these costs are likely to be low at the outset. A client will have expended little on her lawyer by the time the identity of her opponent's lawyer is revealed. Thus, for practical purposes, the game's assumption of a costless opportunity to switch lawyers on the disclosure of opposing counsel is roughly consistent with real litigation patterns. ${ }^{40}$

38. The strategy is "weakly dominant," in the sense that if player $B$ chooses a gladiator, player $A$ is indifferent between choosing a cooperative lawyer and then switching to a gladiator, or instead simply choosing a gladiator.

39. For a discussion of commitment strategies generally, see Thomas C. Schelling, The Strategy of Conflict ch. 2 (1960).

40. Thomas Schelling has called our attention to a possible agency problem at this stage of the pre-litigation game: how does the plaintiff know whether the lawyer chosen by the defendant is a cooperator or a gladiator. If the plaintiff has sufficient experience to make this determination herself, the game is unaffected. However, if the plaintiff must rely on the cooperative lawyer initially chosen to identify the type of lawyer chosen by the defendant, a not unrealistic assumption in many cases, the plaintiff's lawyer confronts a 
The third assumption-that clients cannot change lawyers during the litigation game-is more problematic. At first glance, the assumption seems patently false; a client may discharge counsel at any time. On closer examination, the presence of substantial switching costs may provide a reasonable proxy for a prohibition against discharging cooperative counsel once the litigation is well underway. As litigation proceeds, a lawyer expends substantial time becoming familiar with the law and especially the facts of the case. The client pays for the lawyer's acquisition of this knowledge. The client's investment in the lawyer's knowledge is relationship-specific in the extreme; that is, it is of no value to the client if the lawyer is fired. Thus, the price of firing the lawyer is the cost of bringing another lawyer up to speed in the litigation. While not a prohibition on changing lawyers, switching costs impose a substantial penalty on defection. ${ }^{41}$ Indeed, the longer the litigation continues, the more switching will cost.

Thus, the special assumptions underlying our pre-litigation game are not implausible. What remains, however, is the most critical of the assumptions on which lawyers' potential to facilitate cooperation depends: the existence of lawyers with reputations for cooperation. How and why are such reputations created and sustained? How do clients learn which lawyers are cooperative? ${ }^{42}$

conflict. If the defendant chooses a gladiator and the plaintiff's cooperative lawyer so reports, the plaintiff will switch to a gladiator and the cooperative lawyer will lose the work. Hence, the cooperative lawyer may have an incentive to misrepresent the defense lawyer's type to the client in order to keep the work.

The primary barrier to the cooperative lawyer acting on this conflict is the lawyer's reputation. The cooperative lawyer's special value-why the lawyer can charge a premium-depends on truthful revelation of the defense lawyer's type; otherwise the plaintiff gets the worst outcome: the sucker's payoff where the defendant has a gladiator but the plaintiff has a cooperator. The failure to reveal truthfully the defense lawyer's type would result in the loss of the returns on the cooperative lawyer's investment in reputation. See infra text accompanying notes 149-151

To be sure, that reputation loss requires that misrepresentation of lawyer type in the pre-litigation game be detectable and communicated to clients. However, even clients may recognize the sucker's payoff, a result consistent only with misrepresentation in the prelitigation game. Nonetheless, we believe institutional structure can influence the lawyer's incentive to reveal truthfully the defense lawyer's type. We consider institutional strategies to facilitate truthful revelation of lawyer type infra Part IV.

41. See generally Paul Klemperer, Competition When Consumers Have Switching Costs: An Overview (Centre for Economic Policy Research Working Paper No. 704, 1992) (providing examples of switching costs and describing their effects in the market); Paul Klemperer, Markets with Consumer Switching Costs, 102 Q.J. Econ. 375 (1987) (describing use of switching costs to increase future profits).

42. Ashenfelter and Bloom suggest that the parties' decision to retain lawyers presents a prisoner's dilemma in a setting in which the use of lawyers is optional-that is, the method of dispute resolution allows the parties a realistic option of representing themselves. See Ashenfelter \& Bloom, supra note 7, at 1-2. In their model the cooperative strategy is for both parties to represent themselves; both sides are forced to hire lawyers to avoid the sucker's payoff a party receives when only her opponent hires a lawyer. See id. at 4-5. They present empirical evidence concerning the use of lawyers in a sample of final- 


\section{B. A Reputation Market for Cooperative Lawyers}

The preceding discussion suggests why there might be a demand for cooperative lawyers. Both parties to a lawsuit with a prisoner's dilemma payoff schedule would like to hire cooperative lawyers because that allows them to commit to a cooperative strategy. Clients should therefore be willing to pay a premium for such lawyers, reflecting a portion of the amount by which the cooperative payoff exceeds the noncooperative payoff.

Establishing the supply side is also straightforward. Lawyers would be willing to invest in achieving a reputation for cooperation because they would receive a return on that investment by virtue of the premium fees clients would be willing to pay. As in standard reputation models, the lawyer's investment in reputation serves two functions. First, it identifies the lawyer as one who possesses the desired, but otherwise unobservable, attribute; the client must be able to find a cooperative lawyer. Second, it represents the penalty that the market will impose if the lawyer treats his reputation as bait rather than as bond by turning into a gladiator at the request of an opportunistic client. Noncooperative behavior would forfeit the lawyer's investment in a cooperative reputation. ${ }^{43}$ Thus,

offer arbitration proceedings for New Jersey public safety workers (primarily police officers) that appears to be roughly consistent with their model, see id. at 9-12, and also point to similar results drawn from a sample of employee discharge grievances. See Block \& Stieber, supra note 7 (arguing that, when both sides in employee grievance arbitration have attorneys, awards do not differ from awards given when neither side has an attorney). Ashenfelter and Bloom's account of lawyers' role in litigation is radically different from ours. They model lawyers as "agents of the devil" who sow dissension while ours presents them as doing the Lord's work of facilitating cooperation.

In an important sense, the two models may not be inconsistent. Ashenfelter and Bloom consider circumstances in which parties can, and in their sample quite frequently do, represent themselves: On average, employers appeared pro se in more than two-thirds of the cases, as did unions in more than one-third. Our model is limited to disputes in which lawyers must be retained. Lawyers may well play quite different roles in different dispute resolution settings.

The final-offer arbitration and employee discharge proceedings, at least as described by Ashenfelter and Bloom, appear to more closely resemble our pre-litigation game than a prisoner's dilemma game. If one party to the arbitration or discharge proceeding retains counsel, so apparently can the other; certainly there is no suggestion that a party can keep its retention of counsel secret until it is too late for the opponent to reciprocate. If the parties act sequentially and the first player can costlessly revoke an initial cooperative move if the second player does not reciprocate, there can be no sucker's payoff.

In this setting, the dominant first move is to cooperate by not retaining counsel. Indeed, if the final arbitration or employee discharge procedures did initially have the form of a prisoner's dilemma, the logic of the pre-litigation game suggests a straightforward solution well within the power, and the self-interest, of the parties to adopt: simply require early disclosure of the retention of counsel. Thus, we speculate that there is more going on in the settings considered by Ashenfelter and Bloom; the factors dictating when the parties represent themselves and when they retain counsel are likely more complicated than a prisoner's dilemma.

43. See Benjamin Klein \& Keith B. Leffler, The Role of Market Forces in Assuring Contractual Performance, 89 J. Pol. Econ. 615 (1981) (economic analysis of reputation 
so long as the lawyer's possible loss of investment in reputation exceeds the size of the bribe an opportunistic client would be willing to pay, cooperative lawyers will not be suborned and a market for cooperative lawyers should be available. ${ }^{44}$

However, establishing that clients would demand demonstrably cooperative lawyers and that lawyers would want to supply that service is not sufficient to assure that the market operates. The key word in the previous sentence is "demonstrably." The linchpin of this model is that the lawyer's cooperative or noncooperative behavior be observable. What makes the client's commitment credible is that her lawyer will lose his investment in reputation if he behaves noncooperatively. But this penalty cannot be imposed if the noncooperative behavior cannot be observed. Thus, the structure fails if an erstwhile cooperative lawyer can behave noncooperatively and get away with it. ${ }^{45}$

For this purpose it is critical to follow David Kreps and return to the distinction between observable and verifiable misconduct noted earlier. ${ }^{46}$ That misconduct be observable requires only that the party suffering the affront know with confidence that it occurred. For misconduct to be verifiable, in contrast, the party suffering the affront must be able to demonstrate to an enforcement agency, such as a court, that the misconduct occurred. The difference is important. Verification requires formal proof of misconduct sufficient to meet judicial thresholds. It is commonplace that misconduct which is observable-known to the participantsnonetheless may not be verifiable either because there is no extrinsic proof and the misbehaving party can simply deny the allegations, because the cost of verifying the misconduct is too high, or because the difficulty of defining misconduct limits the legal standard to extreme cases. ${ }^{47}$

and brand name value as means of assuring contract performance). For efforts to use an intermediary as a means of signalling credibility, see Douglas W. Diamond, Financial Intermediation and Delegated Monitoring, 51 Rev. Econ. Stud. 393 (1984) (banks in lending context); Ronald J. Gilson \& Reinier H. Kraakman, The Mechanisms of Market Efficiency, 70 Va. L. Rev. 549, 618-21 (1984) (investment bankers in initial public offerings).

44. See infra Part III.B for an example of such a market.

45. It is possible, of course, that a lawyer with a strong enough preference for cooperation might not defect even if he could get away with it. See Robert A. Frank, Passions Within Reason: The Strategic Role of Emotions 11-19, 91-92 (1988). Framed another way, some lawyers might find the loss of reputation a sufficiently large disincentive to control their behavior.

46. See Kreps, supra note 24 , at 110 .

47. Indeed, efforts to combat noncooperative conduct in litigation by giving the wronged party a cause of action against the party who engaged in misconduct have foundered on precisely this point. The cause of action for malicious prosecution-for bringing purely strategic litigation-is defined so narrowly as to leave most misconduct outside its scope. That has left the professionalism of lawyers as the primary barrier against such conduct. Thus, for lawyers who need only decide privately to withhold their services, the misconduct need only be observable. See Ronald J. Gilson, The Devolution of the Legal Profession: A Demand Side Perspective, 49 Md. L. Rev. 869, 885-86 (1990). 
In our case, noncooperative conduct by one client's lawyer may not be verifiable, but may nonetheless be readily observable by the lawyer on the other side. Recall that the outcome of the pre-litigation game is that both clients retain cooperative lawyers. Thus, one lawyer's subsequent misconduct must, in the first instance, be observable only to the opposing lawyer, not to the client. A trained litigator, himself pursuing a cooperative strategy and completely familiar with the facts of the case, should be able to detect a change in the behavior of opposing counsel. After all, in litigation, noncooperative behavior by one lawyer must operate initially through its impact on the other side's lawyer. ${ }^{48}$ The lawyer can then pass on to the client the fact of noncooperative conduct-the reputation violation-following which both lawyer and client can impose the penalty of lost reputation on the misbehaving lawyer by distributing the information to the legal community. ${ }^{49}$

Thus, the conditions necessary for the operation of a reputation market for cooperative lawyers are plausible, ${ }^{50}$ at least at this level of abstraction.

\section{Agency Problems that May Subvert Cooperation}

The employment of lawyers with identifiable reputations does have the potential to facilitate cooperation between clients in litigation. However, the use of agents to make credible the commitment to cooperate itself poses two potential agency problems. First, the two lawyer-agents may "conspire" to maximize their incomes at the expense of their clients through noncooperative behavior that prolongs the litigation and increases legal fees. When each lawyer stands as gatekeeper against the other lawyer's individual noncooperative misconduct, what protects both clients from the lawyers' joint determination to behave noncooperatively?

48. For an analysis of a lawyer's special position to observe strategic litigation, see id. at 885 .

49. Given the way we have defined the pre-litigation game, the information concerning the misconduct of a previously cooperative lawyer need only circulate within the community of cooperative lawyers. Recall that after the clients disclose their selection of lawyers, any client that has selected a cooperative lawyer may change counsel if her opponent has selected a gladiator. If a "cooperative" lawyer later defects, knowledge of this misconduct within the community of cooperative lawyers would impose the necessary reputational penalty if that lawyer would no longer be considered cooperative. This outcome depends on the loyalty of the nondefecting cooperative lawyer to spread the word within the community.

50. It is beyond the scope of our efforts here to examine the manner in which lawyers would develop the reputation for cooperation; that is, what form the investment in reputation would take. The problem of reputation formation is not straightforward in situations where reputations must be developed by behavior rather than by investment in reputation specific assets like image advertising. See, e.g., Douglas W. Diamond, Reputation Acquisition in Debt Markets, $97 \mathrm{~J}$. Pol. Econ. 828, 829 (1989) (asserting that reputations are developed over time through observation or behavior about some exogenous characteristics of agents). Some of the institutional conditions necessary to reputation formation are considered infra Part III.C. 
Second, a client may subvert a lawyer with a reputation for cooperation. This second problem represents the converse of the first. For a lawyer with a limited number of clients, a particular client may be so important that the threat of withdrawn patronage may induce the lawyer to risk his cooperative reputation by behaving noncooperatively. In other words, there may be circumstances in which incentives may induce a lawyer to abandon his cooperative reputation.

1. A Conspiracy of Agents. - While we proffer lawyers as a means to allow clients to precommit to cooperation, it is only fair to acknowledge that this idea stands current conventional wisdom on its head. The public typically views lawyers as the source of the problem, not its cure. Whitney North Seymour's epigraph to this Article suggests that the problem is not simply that an individual litigator takes advantage of his client, but that opposing lawyers implicitly conspire to take advantage of both clients. Most cases are settled, but not until years of contention run up large legal fees "because lawyers, who benefit most from litigation, are in control-not the clients who pay the bill." 51

Our model leaves room for this type of collusive behavior. While opposing clients who thought that they were each retaining cooperative lawyers would certainly discharge both lawyers if they discovered that the lawyers were conspiring to make lucrative trouble, our story relies heavily on a client's own lawyer to detect misconduct by opposing counsel. During both the pre-litigation game and the litigation itself, a client's lawyer is the first line of defense against noncooperative behavior because many instances of noncooperative conduct will be more easily observed by the lawyer than by the client. Noncooperative conduct that might otherwise be observable to the client may be obscured when the client's lawyer actively participates in its camouflage. ${ }^{52}$ Lawyer collusion thus reduces the observability of misconduct and thereby threatens the structure of lawyermediated cooperation between clients. ${ }^{53}$

2. Giving in to Client Threats. - The second potential problem with using sole practitioners to allow clients to precommit to cooperate results not from the lawyers' collusion against their clients, but from an individual lawyer's willingness to collude with the client. Here the concern is that the very circumstance that creates the potential for cooperation also

51. Seymour, supra note 1 , at A15.

52. One might question how likely it is that clients would fail to observe that a game the client thought would provide a mutual cooperation payoff had been secretly converted to a mutual defection payoff, or, even worse, the sucker's payoff.

53. Two approaches to dealing with the problem of decreased observability come to mind. A familiar argument in the economics of deterrence is that courts can offset decreased detection-in our terms, reduced observability of noncooperation by a reputedly cooperative lawyer-by increasing the penalty for misconduct when actually detected. See, e.g., Robert D. Cooter, Punitive Damages for Deterrence: When and How Much?, 40 Ala. L. Rev. 1143, 1153-59 (1989). Alternatively (or additionally), a client might enhance its own ability to detect noncooperative conduct. For example, the client may invest in in-house general counsel to play this role. 
creates the risk of defection. An individual practitioner can represent only a limited number of clients in ongoing litigation. The larger and more complex the matter, presumably the greater is the opportunity that exists for gain through cooperation. However, the larger and more complex the matter, the greater the percentage of a lawyer's practice it represents, and the more intimidating is a client's threat to change counsel unless the lawyer breaches his reputation. ${ }^{54}$ Because the opposing client would anticipate the risk of defection, in this situation the pre-litigation game might not allow for a cooperative result. ${ }^{55}$

54. As an indication of the danger presented by pressure from a large client, it has been pointed out that the audit fees from Equity Funding, an insurance company involved in a massive policy fabrication fraud, amounted to more than $40 \%$ of the revenues of the audit firm that failed to uncover the fraud. See Linda E. DeAngelo, Auditor Size and Audit Quality, 3 J. Acct. \& Econ. 183, 192-93 (1981). In the law firm context, the firm that did not discover (and was alleged to have participated in) its client's fraud in the OPM leasing scandal is said to have earned $60-70 \%$ of its total revenues from OPM. See Deborah L. Rhode, Ethical Perspectives on Legal Practice, 37 Stan. L. Rev. 589, 628 n.130 (1985).

55. A third problem might arise from the fact that lawyers are short-lived. Reputation models typically assume that the party whose reputation is relied upon has an infinite life. See Rasmusen, supra note 15, at 94-96. Lawyers do not live (or even practice) forever.

From this perspective, one can see the relation between the cooperative lawyer and the opposing client as a one-sided prisoner's dilemma game. The client is asked to choose cooperation (by not changing her cooperative counsel for a gladiator) in reliance on the cooperative lawyer's reputation. Reliance is warranted because if the lawyer behaves noncooperatively, he will be penalized by losing his valuable reputation. But if a lawyer is conducting his last trial, then the penalty cannot be imposed. When a repeated prisoners' dilemma game has a finite (and more or less) predictable end, theory tells it will unravel. See id. at 88-89. This might create "end-game" problems, particularly given how lawyers are likely to develop their reputations.

Assume, not unreasonably, that both a reputation for cooperation and a lawyer's skills take time to develop, so that it is only with age and experience that a lawyer represents clients in litigation involving both large dollar amounts and large potential gains from cooperation. Both assumptions at least theoretically increase the possibility that a cooperative solution will unravel. The larger and more complex the case, presumably the larger the gains from defection and the larger the bribe a lawyer's own client would be willing to offer him to defect. And because the lawyer is retained to handle larger and more complex cases only as his reputation and skills grow with time, he is ever closer to retirement. This pattern would yield the perverse result that, as the size of the bribe offered to the lawyer increases to reflect the increased size and complexity of his cases, the value of the lawyer's reputation decreases because he is that much closer to retirement.

As we will argue infra note 60 , law firms help solve any problem created by the finite professional lives of individual lawyers. However, we are not persuaded that the problem is significant in practice as opposed to theory. A lifetime of cooperation builds an internal perception of self as well as an external reputation. Such self-perception is not so easily given up. See Robert A. Frank, Passions Within Reason: The Strategic Role of Emotions 81, 91 (1988) (asserting that those who are by nature cooperative are most effective at establishing a reputation for cooperation). We note, however, that evidence of reputational final periods does exist. Historical accounts suggest that the problem of short-lived agents in a reputation based market for agents was, in at least one instance, significant and was solved by a practice of holding an agent's sons, who followed the father's business, responsible for the father's prior business dealings. See Avner Greif, Contract Enforceability and Economic Institutions in Early Trade: The Maghribi Traders' Coalition, 83 Am. Econ. Rev. 525, 533 (1993). 


\section{Law Firms and Reputational Commitments}

Problems of self-interest and client pressure hinder the use of sole practitioners as cooperative agents. Using law firms as reputational repositories has the potential to mitigate these problems. But, as with sole practitioners, the game theory-agency theory dialectic also plagues the use of law firms to overcome the problem of credible commitment. Solving the cooperation problem through the use of an organization as primary agent simply exposes a different set of agency problems that arise between the organization and its own agents-the individual lawyers composing the firm.

1. How the Law Firm Might Bond Cooperation When an Individual Lawyer Cannot. - Because a firm may provide a larger repository of reputational capital-at a minimum composed of the aggregate reputational capital of its component lawyers-using a law firm instead of a sole practitioner has the potential to mitigate the problem of collusion between opposing counsel. In effect, the firm pledges its reputation behind the cooperative commitment of each of its lawyers. Defection by any single lawyer in any single case may damage the entire firm's reputation for cooperation. The size of the penalty imposed on the firm for noncooperation in any single case may therefore be larger than the penalty that can be imposed against a sole practitioner for a similar defection. In this way, the difficulties of detection discussed earlier ${ }^{56}$ are balanced by an increase in the penalty if the misconduct is observed.

Additionally, using a law firm in lieu of an individual can directly reduce the potential for collusion. Precisely because the firm allows each lawyer to invoke its entire reputation, the firm has a substantial incentive to monitor the behavior of its own lawyers. Thus, in addition to relying on an individual firm lawyer to detect misconduct on the part of opposing counsel, the client can rely on the firm, acting in its own interest, to monitor the conduct of the particular lawyer actually doing the client's work. ${ }^{57}$

Law firms may also mitigate the problem of unobservable defection in a second, albeit indirect, fashion. Law firms have the skills and capabilities to undertake sophisticated and complex litigation that is beyond the capacity of sole practitioners. ${ }^{58}$ The clients who are parties to such litigation are large commercial concerns that typically have full-time in-house general counsel who were often themselves partners in large law firms earlier in their careers. ${ }^{59}$ As a result, large corporate clients are more

56. See supra text accompanying notes $45-49$.

57. See infra Part II.D.2, for a discussion of whether law firms are homogeneous with respect to the tendency to cooperate.

58. See Marc Galanter \& Thomas Palay, Tournament of Lawyers: The Transformation of the Big Law Firm 115-16 (1991).

59. See Gilson, supra note 47, at 901-03; Ronald J. Gilson \& Robert H. Mnookin, Sharing Among the Human Capitalists: An Economic Analysis into the Corporate Law Firm and How Partners Split Profits, 37 Stan. L. Rev. 313, 381-83 (1985). 
capable of observing noncooperation by opposing counsel and, as a result, the corporate client may be far less dependent on its outside lawyers to monitor opposing counsel. The opportunity for collusion between competing counsel declines as a consequence. ${ }^{60}$

Using a law firm also mitigates the danger that an individual lawyer will be susceptible to economic pressure by his large clients to risk his reputation by behaving noncooperatively. Large law firms often have a diversified client base, with no single client or matter representing a material percentage of total firm revenues. As a result, the size and credibility of the threat posed by a client even in a large matter is reduced ${ }^{61}$ and so, correspondingly, is this danger to a cooperative outcome in the prelitigation game.

2. Agency Problems with Precommitting to Cooperation through Law Firms. - Unfortunately, resorting to law firms to overcome the agency problems of using sole practitioners to mediate a cooperative solution to the prisoner's dilemma does not end the process. It merely evokes the next iteration of the game theory-agency theory dialectic. While reliance upon a firm may mitigate the agency conflicts between lawyer and client, it creates new agency conflicts between the law firm and its agents-the lawyers acting on behalf of the firm. As with sole practitioners, these conflicts threaten the effectiveness of using lawyers to solve the prisoner's dilemma game. This can happen in two ways.

60. To the extent that a sole practitioner's finite professional life presents a barrier to precommitment to cooperation, see supra note 55, a law firm may avoid the problem because of its longer life.

Even a sole practitioner could avoid the problem if the lawyer could sell his practice on retirement for a price that reflected the value of his reputation for cooperation. There would be no final period because any pre-retirement noncooperative behavior by the lawyer would result in the reduction in the sale price of his practice. See Kreps, supra note 24 , at 106-11. The difficulty with this neat solution is that it is very hard to transfer so intangible an asset as personal reputation.

Following Kreps, law firms can be understood, in effect, as a means of facilitating the inter-generational transfer of such personal reputations. Suppose that the reputation for cooperation attaches to the firm rather than the individual lawyer. Then the lawyers in the firm earn a return on their contribution to that reputation during their productive lives from two sources-the extra income the firm earns during their active years, and the amounts paid by the young lawyers for the right to share in the future returns on the firm's reputation through a reduction in the amounts young lawyers receive for their labor in their early years with the firm. By retirement, a lawyer will have been paid for his interest in the firm's reputation for cooperation, essentially having sold it to the firm's next generation of lawyers. This intra-firm sale of reputation effectively mitigates the pressure on the cooperative solution to unravel caused by the fact that individual lawyers are shortlived.

61. We previously pointed out that the auditing firm in the Equity Funding fraud received more than $40 \%$ of its total revenues from Equity Funding. See supra note 54. To see the effect of diversification on the strength of client threats, consider that the largest audit fee of Peat, Marwick, Mitchell represents only 0.5\% of firm revenues. See DeAngelo, supra note 54 , at $192-93$. 
First, law firm income-sharing rules may increase the size of the client's threat. In the previous discussion, we suggested that a law firm's diversified client base diminishes a client's ability to subvert a lawyer with a reputation for cooperation by threatening to withdraw its work. The incentives created by the way a firm splits its income among its lawyers may alter this happy outcome.

It has become commonplace for a law firm to divide its profits among its lawyers based on some measure of the productivity of individual lawyers. ${ }^{62}$ It has also become commonplace for the revenue generated by a lawyer to be treated as a proxy for his productivity, because "real" productivity is unobservable. Within a law firm, the small team of lawyers actually doing the work on a given matter typically makes the litigation decisions; the organizational chart of a law firm's line operations is virtually flat. If an individual lawyer's income is largely a function of the number of hours billed to that lawyer's clients, we must again measure the power of a client's threat to withdraw business not at the firm level, but at the level of the individual lawyer. Even if a client's work is quite small in relation to the firm's total revenues, it nonetheless may loom quite large with respect to the income of the individual lawyer who makes the actual litigation decisions on the firing line.

A similar phenomenon can prompt unnecessarily adversarial behavior even when the client wants to preserve a cooperative solution. Productivity-based profit splitting increases the incentives for collusion between opposing counsel. If the lawyers on both sides of a case are members of firms that split profits in this way, each has an interest in increasing the total billable hours of work required by the dispute.

A final manifestation of this phenomenon yields the same result. Firms pay young lawyers in two ways: current compensation in cash and deferred compensation through the promise of a performance-dependent probability of becoming a partner. Suppose that the probability of becoming a partner depends in important part on the number of hours a young lawyer bills. In many large firms, lawyers who will soon be considered for partnership-senior associates-have substantial authority to influence the extent and intensity of discovery, which is commonly a major source of litigation conflict. In this setting, the senior associate has an incentive to risk the firm's reputation for cooperation by creating conflict; conflict generates additional work and, therefore, an increased probability of making partner. ${ }^{63}$

62. See Gilson \& Mnookin, supra note 59, at 318-20. Productivity based profit division contrasts to profit division based on lock-step seniority, previously the dominant system in a large segment of the law firm community.

63. An analogous problem may also extend to partners. Explaining the large amount of time devoted to a particular matter, an associate at a large firm was reported to have said: "It had something to do with [the fact] that the partner [who] had the matter in our firm felt that he had to get his billings up-thought he had to make a strong impression on the firm at that point in his career." Lisa G. Lerman, Lying to Clients, $138 \mathrm{U}$. Pa. L. Rev. 
The three scenarios described here share a common core. In each, the individual lawyer is in a position to gain-whether through an increased share of current profits or an increased probability of a chance to share in future profits-from actions that risk the firm's reputational capital. And in each, the lawyer gets the bulk of the return from risking the firm's reputation, but bears only part of the loss if that risk is realized. The conflict of interest between the law firm and its lawyers, an agency cost of disputing through a multiple agent entity, threatens the potential for a firm-mediated solution to the prisoner's dilemma game.

Second, client preferences may deconstruct the law firm, thereby reversing the increased investment in reputation that supported any single lawyer's commitment to cooperation. The catch phrase for large clients has become that they "hire lawyers, not law firms." 64 Their goal is to maintain competition among firms for their work by avoiding what Oliver Williamson refers to as the "fundamental transformation"- the shift from market conditions characterized by many competing suppliers to market conditions characterized by one supplier with a substantial advantage over potential competitors as a result of a relationship specific investment following the supplier's initial selection. ${ }^{65}$ A cost to this strategy is the law firm's decreased ability to bond cooperation. Shifting the search for reputation back to the individual from the firm potentially offsets the increase in the size of the reputational capital achieved by moving from individual to firm representation. If it is only the individual lawyer's reputation upon which the client relies, then the aggregate of the reputational capital of the lawyers in the firms does not bond the conduct of the individual lawyers.

That precommitting to cooperate through use of a law firm rather than an individual lawyer evokes its own set of agency problems is not to say that law firms may not be more efficient repositories of reputation than individual lawyers. It merely reflects the operation of the game theory-agency theory dialectic. Any solution to the problem of assuring cooperation in a competitive game that relies on agents generates agency costs. Like friction, we may reduce these costs but we cannot eliminate them. But understanding the ways in which agency incentives can plague cooperative solutions does allow the analysis to take both a positive and a normative turn. Can the prisoner's dilemma heuristic help us understand the observed distribution of cooperation across the institutional landscape of litigation? More tentatively, can the prisoner's dilemma heuristic suggest insights about how to strengthen those institutional ele-

659,707 (1990). Some large firms distinguish between equity and nonequity partners. See Galanter \& Palay, supra note 58, at 62 . A nonequity partner being considered for elevation to equity partner would be in the same position as the senior associate referred to in the text.

64. Gilson \& Mnookin, supra note 59, at 384-86.

65. See Williamson, supra note 23 , at $61-63$. 
ments that facilitate lawyer-mediated cooperative solutions? We now turn to these issues.

\section{UNDERSTANDING THE LANDSCAPE OF LitigATION}

This Part draws on our analysis to understand better the distribution of cooperation across practice settings. We first consider a practice area in which cooperation seems to be diminishing-commercial litigation. Does the prisoner's dilemma heuristic help us better understand the clear public and professional perception that the conduct of large-scale commercial litigation has dramatically deteriorated? We then turn to a practice area in which one can observe persistent pockets of cooperation-family law practice. In each case, the inquiry centers on the characteristics that the prisoner's dilemma heuristic has identified as crucial to a cooperative role for lawyers: the litigation payoff structure and the existence of a workable reputation market. With respect to the former, there must be gains from cooperation. With respect to the latter, the issues revolve about what one might call the costs of scrutiny-the ease with which both clients and lawyers can observe lawyers' reputations and, correspondingly, lawyers' difficulty in credibly establishing reputations for cooperation and their relative gains and losses from breaking these reputations.

\section{A. Understanding the Contentiousness of Commercial Litigation}

Viewing the perceived deterioration in the conduct of commercial litigation through the lens of the prisoner's dilemma suggests two explanations for the increase in contentiousness: a change in the character of the litigation itself; and the impact of growth in the size of the legal community upon the formation and maintenance of reputations for cooperation.

1. The Changing Payoff Structure in Litigation. - Two conclusions about the character of large commercial litigation have emerged in recent years, one empirical and relating to its frequency, the second subjective and relating to its conduct. Recent studies have documented a dramatic increase in the amount of commercial litigation after 1970. A nationwide study of federal court contract cases found that the annual number of filings, after remaining at a relatively constant level of about 14,000 during the 1960 s, began rising in the 1970 s and reached an annual rate of over 47,000 by $1986 .{ }^{66}$ Similarly, a study of breach of contract filings in the Southern District of New York (Manhattan)-the

66. See Galanter \& Rodgers, supra note 4 , at 6 fig. 1 . However, a recent study by Joel Rogers and Terence Dunworth indicates that this trend has since reversed, with contract lawsuits involving Fortune 1000 companies dropping 30\% from 10,253 in 1987 to 7182 in 1991. See Terence Dunworth \& Joel Rogers, Corporations in Court: Big Business Litigation in U.S. Federal Courts, 1971-91, at 7 fig. 2-1 (1993) (unpublished manuscript, on file with Columbia Law Review); see also Milo Geyelin, Suits by Firms Exceed Those by Individuals, Wall St. J., Dec. 2, 1993, at B1, B3. 
federal trial court with what is likely the largest commercial caseload in the country and certainly the court with the largest commercial barfound that contracts cases increased from an average of some 391 cases per year during the 1960s to an average of 1272 cases per year during the period 1973 through 1979, with some years exceeding 1400 cases. ${ }^{67}$ At the same time, the involvement of large New York law firms in these cases increased substantially.

Over the same period, commercial litigators attested to the increasingly uncivil conduct of civil litigation. The phenomenon of discovery abuse was the most obvious manifestation. Over-reaching requests for production were met with dogged resistance to any but perfunctory compliance, and the liberal discovery contemplated by the Federal Rules of Civil Procedure-which aimed to eliminate surprise and facilitate a resolution of the merits based on full information-led instead to trench warfare. Motion and counter-motion, each accompanied by requests for sanctions, created multiple satellite litigation that pushed the merits into the background. ${ }^{6}$

The prisoner's dilemma heuristic suggests a possible link between the empirical fact of increased commercial litigation and the subjective fact that litigation behavior has become significantly more contentious. Recall that in order for lawyers to allow clients credibly to precommit to a cooperative solution the payoffs in the lawsuit must take the form of a prisoner's dilemma: mutual cooperation must have a bigger payoff for each player than mutual defection. If some commercial litigation has payoffs in which one party does not gain from mutual cooperation, such litigation would suffer from defections and be more conflictual. One or both parties would choose gladiators in the pre-litigation game even if that party knew the result would be that the other party would respond in kind.

At least some of the increase in commercial litigation stems from lawsuits in which there were no gains from cooperation. In his study of New York commercial litigation, William Nelson notes that during the 1970s the statutory prejudgment interest rate-the amount a defendant would have to pay a plaintiff on a damage award from the date the damage was suffered to the date of judgment-was no higher than $6 \%$. In contrast, the market rate of interest over the 1974-1980 period ranged from $10.5 \%$ at the end of 1974 to $21.5 \%$ at the end of 1980 , a spread over the statutory rate ranging from $4.5 \%$ to $15.5 \% .^{69}$ Now consider the payoff to a litigation game in which one player owes the other money. As the interest rate spread increases, it becomes more likely that the defendant's dominant strategy will be noncooperation because the gains from the

67. See William E. Nelson, Contract Litigation and the Elite Bar in New York City, 1960-1980, 39 Emory L.J. 413, 413-15 \& n.1 (1990).

68. See, e.g., Brazil, The Adversary Character of Civil Discovery, supra note 25, at $1315-32$.

69. See Nelson, supra note 67 , at $421-22$. 
spread outweigh the transaction costs of conflict: the more conflictual the litigation, the longer the process takes, and the longer the defendant earns the interest rate spread. Indeed, in this game the debtor's best outcome is not the "sucker's payoff" in which the debtor acts noncooperatively and the creditor cooperatively, but "thermonuclear war" in which both sides play noncooperatively-the more conflict, the longer the delay.

This example suggests that the payoff structure of commercial litigation is hardly immutable, and change may well affect the frequency of cooperation. Changes in economic conditions or the rules concerning prejudgment interest can affect the payoff structure of commercial litigation. Some jurisdictions now have rules imposing market-level prejudgment interest in some disputes, ${ }^{70}$ and it is plain that, as legal fees have increased and interest rates have fallen, there may be fewer disputes in which delay so clearly serves one party's interest. Thus, it may be no coincidence that large corporations became much more interested in Alternative Dispute Resolution (ADR) in the 1980s when interest rates were falling and legal costs were increasing. ${ }^{71}$

While the interest rate spread that drove the increase in noncooperative litigation during the 1970s has abated, the phenomenon of strategic litigation, which can have the same payoff pattern, may have replaced it. In this context, litigation is strategic when it seeks not to vindicate a substantive legal right, but when the client uses it as a device to secure a business advantage by imposing costs on the opposing party. ${ }^{72}$ Examples include litigation brought by a target company simply to delay

70. For example, interest charges in tax disputes with the government substantially damp any economic incentive for delay on the part of taxpayers. See I.R.C. § 6601 (1988 \& Supp. II 1990). Section 6601 of the Internal Revenue Code requires payment of interest, compounded daily, on underpayment, nonpayment, and delayed payment of taxes.

Previously, the general interest rate charged on underpayments . . . often did not correspond to the prevailing commercial interest rate, thereby encouraging taxpayers to borrow from the government in periods of high interest rates by underpaying taxes. In order to avoid this situation and to bring interest rates for taxes roughly into line with commercial interest rates, the interest rate on underpayments . . . is no longer fixed but is adjusted according to methods described in Section 6621 of the Code.

Michael I. Saltzman, IRS Practice and Procedure I 6.01 (2d ed. 1991).

A majority of states allow for the recovery of prejudgment interest in specified tort claims. See Note, Prejudgment Interest in Personal Injury Claims, $25 \mathrm{~J}$. Marshall L. Rev. 595, 606 (1992). For a discussion of how prejudgment interest may encourage settlement and reduce delay, see id. at $615-17$.

71. See Geyelin, supra note 66, at B3 (discussing Rogers and Dunworth study noting $30 \%$ decrease in contracts casts involving Fortune 1000 companies from 1987 to 1991, and noting "growing willingness to settle disputes through arbitration and mediation").

72. For a more formal development of this concept of strategic litigation, see Cooter \& Rubinfeld, supra note 5, at 1083-84 (defining action as strategic when it affects only the other party's costs and not the action's likelihood of success or size of recovery). 
a hostile takeover, ${ }^{73}$ or trade secret litigation brought against former employees of a high technology company who leave to form a start-up venture, with the goal of creating sufficient uncertainty that financing is unavailable and the venture fails. ${ }^{74}$ As with strategies exploiting a positive interest rate spread, the payoff structure in this type of litigation is such that for one party the dominant strategy is noncooperation.

Explanations for the increased incidence of such litigation are varied and still at the stage where the boundary between empirical evidence and speculation is blurred. Nelson points to the opening of management to new groups who feel less constraint in treating litigation as part of the competitive environment, and to the increased bureaucratization of management. ${ }^{75}$ Marc Galanter and Joel Rodgers stress the general increase in business instability resulting from such things as the internationalization of competition and increased business failures. ${ }^{76}$ From our perspective, however, the cause is less important than the fact that, as evidenced by developments in commercial litigation, the prisoner's dilemma heuristic helps isolate the settings in which lawyers cannot serve to facilitate cooperation. ${ }^{77}$

2. The Size of the Legal Community and Reputations for Cooperation. Central to the potential for lawyers to facilitate a cooperative solution to a prisoner's dilemma litigation game is an effective reputation market for lawyers. Lawyers must be able to earn and maintain observable reputations for cooperation, and lawyers must be able to observe breaches of reputation by opposing counsel and have an interest in reporting these breaches. There is reason to believe that the enormous growth in size of the large law firms that provide legal representation in most substantial commercial litigation has undermined the effectiveness of the reputation market.

73. See Herbert M. Wachtell, Special Tender Offer Litigation Tactics, 32 Bus. Law. 1433, 1437-38 (1977).

74. See Alexander E. Silverman, Symposium Report: Intellectual Property Law and the Venture Capital Process, 5 High Tech. L.J. 157 (1990) (Summary of Symposium Sponsored by the Stanford International Center for Law and Technology and the John M. Olin Program in Law and Economics, reporting the results of a survey of 30 San Francisco law firms active in intellectual property disputes against start-up companies); cf. Victoria Slid-Flor, More Trade Secret Wars, Nat'l L.J., Mar. 22, 1993, at 1, 34-35 (noting that startups should include cost of trade-secret litigation in their budgets); Udaya Gupta, Start-Ups Face Big-Time Legal Artillery, Wall St. J., Oct. 31, 1988, at B2 (discussing rise in number of patent and copyright suits brought against start-ups).

75. See Nelson, supra note 67 , at $427-48$.

76. See Galanter \& Rodgers, supra note 4, at 50-53.

77. Lawyers have traditionally been thought to have a professional responsibility to prevent strategic litigation, but this obligation serves not to facilitate cooperation among clients who seek cooperation, but to impose cooperation on clients who prefer conflict. See Gilson, supra note 47 , at 886 . The lawyer's ability to reduce litigation conflict in this fashion depends importantly on informational asymmetry between lawyer and client. See id. at 889 . 
The first step in the analysis is to recognize the extraordinary growth of large law firms. In the late 1950s, only 38 law firms had more than 50 lawyers. By 1985, 508 firms had reached that size. Fewer than a dozen firms exceeded 100 lawyers in 1960; by 1986, there were 251 such firms. In 1968, the largest law firm had 169 lawyers; ${ }^{78}$ in 1993 the largest firm had 1662 lawyers and 184 firms were larger than the 1968 leader. ${ }^{79}$

Now consider how lawyers might develop a reputation for cooperation. Suppose that the primary vehicle of reputation formation is a lawyer's relations with other lawyers, who then communicate that reputation to the client community. As discussed earlier, this is a plausible assumption given that cooperation in litigation is not a bright-line concept; because litigation is inherently competitive, a reputation for cooperation will be based on the more ephemeral concept of not being too conflictual. This type of standard requires that a lawyer apply it in the first instance.

In this setting, repeated experience with the same lawyers facilitates the formation of a cooperative reputation because competing lawyers are able to factor out the noise associated with the lawyer's conduct in any particular matter. The number of times that one lawyer has the experience of litigating against another lawyer in the community is a function of the size of the community-the smaller the community, the easier it is for lawyers to learn about the predilections of their adversaries toward cooperation.

These circumstances are sufficient to predict a secular trend of decreased reputations for cooperation among law firm lawyers in a rapidly growing legal community. Lawyers will perceive members of the older generation of lawyers as having a reputation for cooperation, their reputations having been developed in a less populated environment. ${ }^{80}$ In this environment, leading litigators in a community dealt with each other every day. In contrast, the succeeding generations of lawyers would have found it much more difficult to develop reputations for cooperation because the continued growth of the legal community decreased their opportunity to have had sufficient dealings with a large enough segment of the bar to have developed one. ${ }^{81}$ In these circumstances, if a lawyer can-

78. See Galanter \& Palay, supra note 58, at 46.

79. See The NLJ 250, Nat'l L.J., Sept. 27, 1993, at s4, s5-s22. Indeed, Galanter and Palay argue that law firm growth rate has been essentially exponential. See Galanter \& Palay, supra note 58 , at $87-89$.

80. In the early 1960s, when only 38 law firms had more than 50 lawyers, 21 of those firms were located in New York and only 17 in the entire rest of the country. See Galanter \& Palay, supra note 58, at 22.

81. The importance of the size of the community of litigators and their need to interact to establish cooperative reputations suggests an interesting interpretation of the institutional features of the British bar. The separation of barristers and solicitors, the maintenance of effective limits on the number of barristers and their housing in inns of the court, assuring out-of-court proximity and interaction, combine to create an environment quite conducive to reputation formation and maintenance. See, e.g., Robert Megarry, Barristers and Judges in England Today, 51 Fordham L. Rev. 387, 388-92 (1982). 
not develop a reputation for cooperation, then the dominant career strategy is noncooperation - to be a gladiator. Thus, with the passage of time, as the older lawyers retire and are replaced by younger lawyers, the legal community becomes dominated by lawyers with a noncooperative style and conflict in litigation increases over time.

To be sure, most lawyers do not identify themselves as bombers or gladiators. Rather, they describe their personal strategy as flexible, either cooperator or gladiator, depending on how the other side plays. In effect, the picture is of a population of tit-for-tat lawyers: each cooperates until the other side defects and then retaliates. ${ }^{82}$ Wrapping oneself in the cloak of tit-for-tat does have a powerful rhetorical effect. Not only is blame for observed conflict placed on the other lawyer-retaliation comes only after the other side defects-but it also carries a strong claim of effectiveness. In Robert Axelrod's now classic tournament, tit-for-tat proved the most successful strategy for playing a repeated prisoner's dilemma game. ${ }^{83}$

The puzzle, then, is to explain what generates all the litigation conflict. If litigators generally claim that they always cooperate unless the other side defects, who is left to defect first? The problem is that the effectiveness of the tit-for-tat strategy depends on a particular characteristic of the environment in which the game is played. As typically stated (and as was the case in Axelrod's tournament), the tit-for-tat strategy assumes that each player has perfect information about the other player's actions. That is, each player knows with certainty whether the other player has cooperated or defected. ${ }^{84}$ In contrast, when one player may mistake the character of the other player's actions, tit-for-tat leads not to cooperation, but to continuing gladiatorial defection. Suppose one player misinterprets her opponent's action as defection when her oppo-

This is consistent with the common observation that British litigation is far less conflictual than in the United States. See Graham Hughes, English Criminal Justice: Is it Better than Ours?, 26 Ariz. L. Rev. 507, 589, 607-09 (1984); Janice Toran, Settlement, Sanctions, and Attorneys Fees: Comparing English Payment into Court and Proposed Rule 68, 35 Am. U. L. Rev. 301, 311-15 (1986); cf. Cook, supra note 9, at 984-87 (advocating American Inns of Court modelled after the English system as a means of "tam[ing] Rambo lawyers"); Benajamin Kaplan, An American Lawyer in the Queen's Courts: Impressions of English Civil Procedure, 69 Mich. L. Rev. 821, 822-26, 832 (1971) (discussing how English system holds down costs in investigation and discovery stages of litigation).

82. More completely, a tit-for-tat strategy dictates that the party cooperate on the first move and thereafter do whatever its opponent did on the prior move. Thus, the strategy requires a player to be both provokable and forgiving. It leads to retaliation in response to defection, but then will lead back to cooperation if an opponent returns to cooperative play after a previous defection. See Axelrod, supra note 22, at 31, 34-35.

83. See id. at 32. Axelrod's study is discussed supra text accompanying notes 32-33.

84. See Bendor et al., supra note 36 , at 692 ; Jonathan Bendor, In Good Times and Bad: Reciprocity in an Uncertain World, 31 Am. J. Pol. Sci. 531, 532-33 (1987); see also Per Molander, The Optimal Level of Generosity in a Selfish, Uncertain Environment, $29 \mathrm{~J}$. Conflict Resol. 611 (1985) (discussing vulnerability of tit-for-tat strategy to disturbances and how to overcome them). 
nent actually meant to cooperate. Tit-for-tat dictates following the opponent's move on all moves after the first. Thus, cooperation ends after the misinterpretation. One player defects, mistakenly thinking her opponent had done so, and her opponent then follows suit, the mistake "echoing" back and forth as the players simply repeat the initial mistake. ${ }^{85}$

Thus, the information structure of the litigation game can explain the presence of significant conflict in litigation even though most lawyers claim to play tit-for-tat. Litigation is quite "noisy." Clearly identifying whether the other side has cooperated or defected in a competitive environment where cooperation is defined as being not too conflictual, is often quite difficult. For example, not all objections to discovery requests are defections.

Uncertainty over the character of the game compounds the uncertainty over whether an opponent has cooperated or defected in a particular round. Recall that only some litigation has the payoff structure of a prisoner's dilemma. ${ }^{86}$ Evaluating an opponent's action also requires correctly evaluating the litigation itself-noncooperation does not constitute defection if there is no possibility of gaining from cooperation.

When there is uncertainty about both the players' moves and the nature of the game, a tit-for-tat strategy results in more conflict rather than less. ${ }^{87}$ Moreover, because of the tendency for a noisy prisoner's dilemma game between two tit-for-tat players to degenerate into repeated defection following an initial mistake, the systemic increase in conflict is exacerbated by increases in the percentage of tit-for-tat players in the environment.

Indeed, the potential for law firms to develop reputations for cooperation may not save civilized litigation as the older generation knew it. As we saw in the previous subpart, there is reason to believe that the proportion of litigation whose payoff structure does not reward mutual coopera-

85. See Avinash K. Dixit \& Barry J. Nalebuff, Thinking Strategically: The Competitive Edge in Business, Politics, and Everyday Life 107-13 (1991). In fact, the echoing need not be endless. It will stop if at some point one of the players makes the opposite mistake, misinterpreting defection for cooperation. Interestingly, it seems not to make any difference how likely it is that a player make a mistake. If an initial mistake is never corrected, the echoing will be endless. If, instead, mistakes occur randomly, two players following a tit-for-tat strategy will spend half the time cooperating and half defecting. A small likelihood of a mistake occurring is exactly offset by the longer period before it is corrected by another mistake. However, if the likelihood of misperception reaches $50 \%$, the dominant strategy will be always to defect. Because nothing you do will alter your opponent's response-he will always guess wrong half the time- there is no reason not to defect. See id. at 112.

86. See supra Part III.A.1.

87. The simulation literature supports the analytical result. In contrast to its winning performance in the original Axelrod tournament, when an Axelrod style tournament was run with the addition of noise, tit-for-tat's performance was "mediocre, placing eighth out of the 13 strategies." Bendor et al., supra note 36 , at 696 . The winning strategy was more forgiving of defection than tit-for-tat, with repeated defection serving to eliminate the likelihood that the conduct is misinterpreted. See id. at 696-97. 
tion may have increased in the 1970 s and $1980 \mathrm{~s}^{88}$ If a large law firm represents clients both in litigation in which mutual cooperation is beneficial and in litigation in which the dominant strategy for one party is to compete, reputation formation becomes much more complicated. The observation of noncooperative behavior is then consistent either with a noncooperative lawyer or noncooperative litigation. ${ }^{89}$

The same problem also hinders the maintenance of reputations. For a reputation market to work, defections by cooperative lawyers must be observable. However, both aspects of noise we have considered-a mixed environment of cooperative and noncooperative litigation, and the difficulty of evaluating whether a particular action by an opponent is cooperative when the standard for cooperation is being not too competitivemakes observation of defection more difficult.

\section{B. Understanding the Presence of Cooperation in Family Law Practice}

We now consider whether one can also apply the prisoner's dilemma to help understand a practice setting in which, unlike large commercial litigation, cooperation between opposing counsel is plainly observablematrimonial practice. Given the different institutional characteristics in commercial litigation on the one hand, and divorce law on the other, does the prisoner's dilemma heuristic explain different levels of cooperation?

1. The Payoff Structure in Divorce. - The first step in applying the prisoner's dilemma heuristic to family law practice is analysis of the payoff structure. If lawyers are to have the potential to credibly commit their clients to cooperate, there must be gains from cooperation (and the risk of loss if the other party defects). Put in context, divorce litigation must be more than a zero-sum game in which the couple's property and children are simply divided.

Divorce bargaining is sometimes seen as a purely distributive (zerosum) game in which any benefit to the wife necessarily comes at the husband's expense, and vice versa. Both the money issues and the custody issues do have distributive elements with zero-sum characteristics. When a divorcing couple divides $\$ 2,000$ in a checking account, a $\$ 100$-larger share to the wife necessarily results in a $\$ 100$-smaller share to the husband. Similarly, if a father must transfer more of his paycheck to the mother's household by way of support, there are fewer funds available to spend on himself. Division of the child's time also displays this distributive feature. When a child spends more time in one household, this necessarily reduces the time potentially spent in the other.

88. See supra Part III.A.1.

89. To the extent the lawyer has established a credible reputation for cooperation, the party's selection of a lawyer may also signal the party's beliefs about the payoff structure in the particular case subject to the pre-litigation game, see supra note 40 , and might ameliorate the problem somewhat. We return to this point in Part IV in connection with development of institutional strategies to facilitate cooperation. 
But divorce bargaining is hardly a zero-sum game in its entirety: in many circumstances, cooperation can "create value" and improve the outcome from each party's point of view. ${ }^{90}$ First, and most fundamentally, not all of the father and mother's interests are at odds. Parents often share a fundamental interest in the well-being of their child. If the child does well, both parents are better off. Therefore, devising an arrangement that benefits the child potentially creates joint gains for both parents. Parental cooperation in co-parenting may improve opportunities for the children, and thus both parents may benefit. Even if childless, a divorcing couple may have other shared interests as well. Reducing the costs of divorce-financial and emotional-once again may benefit both parties. To the extent that the parties can reduce the transaction costs of divorce, they obviously increase the financial and emotional resources available to build new lives. In addition to other interests the divorcing spouses may share, ${ }^{91}$ there are potential gains realizable from the parties' preferences and the differences in relative values that they may attach to different assets or activities. "This means that there can be gains-and value created-through trades." 92 Cooperation allows divisions to be based upon the parties' personal preferences, rather than the impersonal relative valuations of the market or a court.

While it is obvious that divorcing parents can sometimes themselves devise arrangements that benefit both themselves and their children, a number of potential barriers to cooperation make the divorce lawyer's role critical. For one thing, the strong emotions attending divorce may pose a formidable barrier to collaborative rational problem-solving.

Joint problem-solving and negotiation work best with clear communication and good listening skills. Many couples lacked these skills during the marriage itself, and divorce is obviously an extremely difficult time to develop them. Indeed, many couples may replay in the divorce process old and dysfunctional patterns of dealing with each other during the marriage, and these patterns may make cooperation difficult or impossible. ${ }^{93}$

When inexperience, inability, or a soured relationship prevent divorcing spouses from cooperating themselves, the payoff structure of divorce proceedings may frequently take the form of the prisoner's dilemma. Cooperative divorce lawyers may therefore provide an escape: by credibly committing their clients to cooperate, the lawyers as in-

90. This discussion and characterization of the task facing divorcing spouses draws on Eleanor E. Maccoby \& Robert H. Mnookin, Dividing the Child: Social and Legal Dilemmas of Custody 52-54 (1992).

91. In some cases, "both parents may share a long-run interest in the financial independence of the wife. By subsidizing additional education for the mother, thus increasing her independent earning potential, a father may benefit not only his wife but himself as well because of her decreased dependence." Id. at 53.

92. Id. at 54; see Robert H. Mnookin \& Lewis Kornhauser, Bargaining in the Shadow of the Law: The Case of Divorce, 88 Yale L.J. 950, 969 (1979).

93. Maccoby \& Mnookin, supra note 90 , at 55 . 
termediaries may be able to create gains that the spouses could not realize alone.

The potential for the sucker's payoff is also present. In the divorce process, cooperative moves by one side-if not reciprocated by the other side-may lead to exploitation. Opportunities for strategic behavior likewise exist because the parties often will not know with certainty (1) the other side's true preferences regarding the allocation of assets; (2) the other spouse's preferences or attitudes toward risk; and (3) the likely outcome in court if they do not settle their disputes. Some matrimonial lawyers are known as "bombers," or Rambo types who will defect in a variety of ways: by contesting custody on behalf of a client who is really interested in simply paying less support; by vigorously resisting the disclosure of relevant financial information; and by generally using discovery requests and responses, depositions, and motions to wear down the other side in what amounts to a war of attrition..$^{94}$

2. The Institutional Structure of the Divorce Bar. - Not only is the payoff structure in divorce proceedings consistent with a cooperative role for lawyers, but the institutional structure of family law practice appears to allow lawyers, at least in some instances, to create and sustain reputations for cooperation (and noncooperation). Family law practice tends to be both localized and specialized. A divorcing husband and wife usually hire attorneys in the same legal community. Increasingly, some lawyers have tended to specialize in family practice, especially in metropolitan areas. Typically, over a period of time, these local specialists repeatedly deal with one another. Through this repeated exposure lawyers can develop and sustain their reputations.

Professional organizations for family law specialists appear to facilitate this process of reputation development and maintenance. For example, the American Academy of Matrimonial Lawyers, a self-anointed elite of the family law bar, seems to exist for the principal purpose of providing an efficient reputational network among family lawyers. All of its members are specialists who are frequently involved in divorces of wealthy individuals. ${ }^{95}$

94. See, e.g., Richard E. Crouch, The Matter of Bombers: Unfair Tactics and the Problem of Defining Unethical Behavior in Divorce Litigation, 20 Fam. L.Q. 413, 415-34 (1986); Monroe Inker, Abusive Tactics in Depositions, 26 Fam. L.Q. 27-41 (1992).

95. The American Academy of Matrimonial Lawyers was founded in 1962 by a small group of nationally known family law specialists. The stated purpose was to "encourage the study, improve the practice, elevate the standards and advance the cause of matrimonial law." American Academy of Matrimonial Lawyers Informational Pamphlet (n.d.) (on file with the Columbia Law Review). There are now more than 1200 Fellows and 22 chapters of the Academy throughout the United States. Local chapters meet regularly to provide opportunities for "[p]rofessional and social fellowship," one of the "key features of Academy membership." Id. The Academy selects as members only those family law specialists who are "recognized by their fellow lawyers and by the judges where they practice as the top experts in their field." Id. In interviews with members of the Northern California chapter, members described the Academy as a "powerful source of contacts and information," Interview with Attorney A, in Field Notes on Academy Member Interviews 1, 
Interviews with California family law specialists ${ }^{96}$ suggest that a reputational market does exist; that some lawyers cultivate reputations as cooperative problem-solvers, while others are viewed as more adversarial, both by themselves and others; and that, as suggested by our pre-litigation game, there is a substantial amount of self-selection both by clients and attorneys. The small sample size and the informal methodology of our survey mean that one should view our conclusions only as suggestive, but the anecdotal evidence we have gathered seems consistent with our framework.

Not surprisingly, the Academy members that we interviewed all knew each other from prior first-hand dealings; they readily and consistently characterized each other either as cooperative problem-solvers or as more adversarial gladiators. ${ }^{97}$ The lawyers interviewed suggested that most Northern California members of the Academy have a problem-solving orientation, at least when involved in a case in which opposing counsel was also an Academy member. However, the members consistently described a smaller number of members as being more adversarial.

All of the cooperative problem-solvers whom we interviewed reported that over half of their practice (as measured in terms of income) involved cases in which an Academy member also represented the other spouse. ${ }^{98}$ With the exception of cases involving known gladiators, members of the Academy typically voluntarily exchanged information and documents reciprocally and informally. Because opposing counsel knew and trusted each other, they rarely insisted on interrogatories, depositions, or engaged in protracted formal discovery. ${ }^{99}$

1 (1993) (on file with authors) [hereinafter Field Notes], which provides members with "knowledge of each other's propensities." Interview with Attorney D, in Field Notes, supra, at 11 . The interviews are described infra note 96 .

96. In order to explore cooperation among family lawyers, Professor Mnookin discussed these issues with 20 California family law specialists attending a week-long retreat during Fall 1992. A number of these lawyers were members of the Academy. In Spring 1993, with the help of George Lichter, in-depth interviews were conducted with five members of the Northern California chapter of the Academy-three of whom other members had identified as having a reputation as cooperative problem-solvers, and two of whom had reputations for being adversarial. As part of the interview, each was asked to describe his or her own style and reputation, and the reputations of nine other Academy members, including the others who were interviewed. To maintain confidentiality, the names of all of the lawyers interviewed and discussed have been omitted, and the letters $\mathrm{A}$ through $\mathrm{M}$ have been consistently substituted.

97. For support for the proposition that members readily characterize each other as cooperative or adversarial, see Interview with Attorney A, in Field Notes, supra note 95, at 8-10; Interview with Attorney D, in Field Notes, supra note 95, at 13, 16-18; Interview with Attorney B, in Field Notes, supra note 95, at 24-26; Interview with Attorney E, in Field Notes, supra note 95, at 28, 31, 33; Interview with Attorney C, in Field Notes, supra note 95, at $36-40$.

98. See, e.g., Interview with Attorney A, in Field Notes, supra note 95, at 10; Interview with Attorney D, in Field Notes, supra note 95, at 16.

99. For examples of cooperative practices between cooperators, see, e.g., Interview with Attorney A, in Field Notes, supra note 95, at 2-3; Interview with Attorney D, in Field 
Not surprisingly, the interviews suggested that cooperative problemsolvers much preferred dealing with lawyers who shared their orientation. A great deal of sorting and self-selection appears to occur based on reputation. Lawyers who saw themselves as cooperative said they would describe their problem-solving orientation during initial meetings with clients. They reported that their clients often were seeking lawyers with a particular orientation. ${ }^{100}$ Several cooperative lawyers reported that they regularly turned away clients who sought highly adversarial representation. ${ }^{101}$ As one stated, "If a client is hell bent upon hiring an advocate to disembowel the adverse party, I direct them elsewhere."102 They also suggested that such clients rarely approached them in the first place. "Clients tend to preselect their lawyers, and for whatever reason, if one spouse has chosen Attorney F, the other spouse is unlikely to seek me out."103 Attorney F and Attorney D, known gladiators, were said to be chosen typically by clients who shared their outlook. ${ }^{104}$ When these attorneys are hired, lawyers on the other side are very aware of the ramification for their clients and the dispute resolution process. ${ }^{105}$

The cooperative problem-solvers did report that they sometimes represented a spouse when a bomber was representing the other spouse. They typically did not enjoy the process.

Every time you have a case with Attorney F, you're going to court and it's going to be big bucks. . . . She has a manner of presenting her arguments which is very off-putting. It's ugly, contentious, constantly picking at the other lawyer-“why didn't you do this; you said you were going to do something; once

Notes, supra note 95, at 13; Interview with Attorney C, in Field Notes, supra note 95, at 38-39. Examples of defection are described in Interview with Attorney A, in Field Notes, supra note 95, at 4; Interview with Attorney C, in Field Notes, supra note 95, at 34, 37.

100. See, e.g., Interview with Attorney A, in Field Notes, supra note 95, at 7; Interview with Attorney B, in Field Notes, supra note 95, at 26; Interview with Attorney C, in Field Notes, supra note 95, at 35 ("Most people seek out the lawyer whose style most clearly reflects their own emotional state regarding the dispute. If they come to [me], the odds are the client wants a 'milder approach' and prefers to reach settlement. Others just want the meanest son-of-a-bitch around so they can inflict as much pain as possible on the other spouse.").

101. For examples of cooperative lawyers turning away clients looking for gladiators, see Interview with Attorney A, in Field Notes, supra note 95, at 7-8; Interview with Attorney B, in Field Notes, supra note 95, at 19.

102. Interview with Attorney A, in Field Notes, supra note 95, at 7-8.

103. Id.

104. See id. at 9; Interview with Attorney B, in Field Notes, supra note 95, at 26.

105. See Interview with Attorney A, in Field Notes, supra note 95, at 8 ("every time you have a case with Attorney F, you're going to court and its going to be big bucks"); Interview with Attorney A, in Field Notes, supra note 95, at 9 ("When Attorney D is involved, I let my clients know they are in for the whole dance."); see also Interview with Attorney A, in Field Notes, supra note 95, at 5; Interview with Attorney E, in Field Notes, supra note 95, at 36 . A former president of the Academy, who characterizes himself as a titfor-tat player who is willing either to cooperate or to fight, indicated that "my 60th birthday present to myself is never to handle another case against [a Los Angeles firm consisting only of bombers]." Interview with Attorney H, in Field Notes, supra note 95, at 43. 
again you haven't done what you said you were going to do"repetitive nagging. ${ }^{106}$

A cooperative attorney described another gladiator, Attorney $\mathrm{D}$, as "miserable to have a case with" because he insists on litigating everything. "He really doesn't care about the answer, he cares about the process and the process goes from start to finish and doesn't stop; ... he works every nook and cranny." 107 This same gladiator was described by another interviewee as constantly taking "unreasonable stances; ... . he goes to court much too much, and overtries a case." 108 Interestingly, Attorney D described himself in our interview in very similar terms, although without the uncharitable spin. "I like to try cases, and I love to dream up new legal arguments, and then have the judge decide."109

A final feature of matrimonial practice may also facilitate cooperation. Unlike a commercial litigator, a family law specialist is usually not unduly dependent upon a single client for his or her livelihood. This should make it easier for a cooperative problem-solver to resist client pressure to defect after the case is underway.

We do not mean for our analysis of family law practice to suggest that matrimonial practice is exclusively or even predominantly cooperative. Instead, we use matrimonial practice to illustrate that reputational markets presently exist that permit clients to commit to cooperative strategies in circumstances in which the clients themselves might have great difficulty doing so. Our informal survey of San Francisco matrimonial specialists strongly suggests that the relationship between lawyers known to each other to have cooperative, problem-solving orientations facilitates dispute resolution.

\section{Institutional Features Conducive to Cooperation: Some Tentative Generalizations}

Imagine a lawyer entering a legal community for the first time. The pattern of cooperation within the community is obviously crucial to the lawyer's professional survival. What questions should the lawyer ask to help appraise the community's cooperative character? Our comparison of commercial litigation and matrimonial practice suggests several institutional features that are central to assessing lawyers' potential to facilitate cooperation between their clients. The size of the legal community, the incentives arising out of the lawyer's practice setting, and the complexity of the legal environment are all critical in determining the observed level of cooperation, and thus the legal culture in a given community.

1. The Size of the Legal Community. - The size of the legal community greatly influences the strategies available to build and observe the cooper-

106. Interview with Attorney A, in Field Notes, supra note 95, at 8.

107. Id. at 9.

108. Interview with Attorney B, in Field Notes, supra note 95, at 25.

109. Interview with Attorney D, in Field Notes, supra note 95, at 12; see also id. at 11, 15 , for similar comments. 
ative reputation that serves as a bond against a cooperator turning gladiator. Where the legal community is small, lawyers can learn about each other's practice style experientially through repeated first-hand dealings. The larger the number of lawyers, the longer it will take through direct contact to acquire sufficient reliable information about the reputation of other lawyers. Thus, when the legal community is large, reputation formation is more costly and one would expect lower levels of cooperation, other things being equal.

In his 1980 study of civil discovery in Chicago, Wayne Brazil reported that his interviews reflected the importance of the size of the legal community on lawyer conduct. When "regulars" 110 -i.e., specialists in a given area who saw "themselves as forming a loose, informal fraternity of specialist peers"111-litigated against one another, discovery was less likely to be burdened with tactical jockeying, harassment, evasion, and other forms of resistance to disclosure than when the other party was inexperienced or unfamiliar with established practitioners in the field. ${ }^{12}$ Among the explanations offered by Brazil is that these Chicago "regulars" constitute a community, not unlike that of small town lawyers, in which "social and professional pressures" constrain and shape behavior. Moreover, because they expect to have significant social and professional contact in the future, opposing counsel know they will have "opportunities to retaliate for any perceived mistreatment by a fellow lawyer." 113

Anecdotal evidence strongly suggests that cooperation is more difficult to sustain in large communities. Even among members of the elite of the matrimonial bar, it appears that divorce practice in New York and Los Angeles is on average more adversarial than in San Francisco. Like San Francisco, New York and Los Angeles have active chapters of the American Academy of Matrimonial Lawyers, but the size and culture of these larger communities leads to a more adversarial bar. ${ }^{114}$ In a larger community, it is more difficult for a lawyer to have repetitive, first-hand experiences with all of the other "major players." The result is a more contentious Los Angeles family law practice even among members of an elite professional organization that has adopted explicitly cooperative

110. According to Brazil:

"regulars" refers to groups of lawyers (1) who are experienced and regularly practice in a few closely related substantive areas of civil litigation . . ; (2) who practice for the most part in the same city or limited geographic area; (3) whose work is likely to bring them into contact with one another more than occasionally; (4) who know one another or at least one another's firms; and (5) whose practice "styles" are either similar or well known and essentially accepted by one another.

Wayne D. Brazil, Views from the Front Lines: Observations by Chicago Lawyers About the System of Civil Discovery, 1980 Am. B. Found. Res. J. 217, 240.

111. Id.

112. See id. at $240-41$.

113. Id. at 241-42.

114. Field Notes from Weekend Retreat, in Field Notes, supra note 95, at 45. 
practice guidelines. ${ }^{115}$ In a large community, different strategies to achieve cooperation are required because the community's size does not allow reputation development to be based on first-hand experience.

2. The Lawyers' Incentives. - The game theory-agency theory dialectic highlights that using lawyers to commit their clients' cooperation inevitably creates agency costs. Because these costs corrode the credibility of lawyers' commitment, the more extensive the agency costs, the less successful will be lawyers' efforts to facilitate cooperation through intermediation. Thus, detailed information about the structure of the practice would be very helpful. For example, how are lawyers paid-by the hour or by outcome? In firms, on what basis are partnership profits dividedseniority or productivity? On what basis are associates promoted? The point is that the organization of practice can influence the level of cooperation within the legal community, and that the influence can run in both directions. Features of law firm organization shifted rapidly during the 1980s, as increased sophistication among consumers of law firm services combined with unprecedented demand for complex legal services to weaken the bonds of firm specific capital. ${ }^{116}$ The business and legal environment of the 1990s may be quite different, stressing cooperative business ventures and alternative dispute resolution rather than hostile takeovers and thermonuclear litigation. To that extent, law firm organization may require reshaping to facilitate a more cooperative style of practice.

3. Complexity. - Noise is the enemy of cooperative strategies. The more difficult it is to tell whether one's opponent is cooperating, the more likely it is that mistakes will occur, leading to unnecessary conflict. At the extreme, mistaking cooperation for defection a single time can result in eternal conflict between tit-for-tat players. ${ }^{117}$ We hypothesize that as litigation grows more complex the parties are less likely to understand fully their own and their opponent's interests, and as a result, their opponent's actions will grow noisier. Noise, in turn, leads to misunderstanding and unnecessary conflict.

Increased complexity of the legal environment has the same effect; noise may also exist concerning whether cooperation is appropriate at all. As we have seen, the potential for lawyers to facilitate cooperative strategies depends on the payoff structure of the litigation game: there must be gains from cooperation. ${ }^{118}$ A legal environment that contains both litigation that has the payoff structure of a prisoner's dilemma and litigation in which one party's payoff from mutual defection is greater than through mutual cooperation adds an additional level of noise. The parties must correctly identify the nature of the particular litigation in which they are involved-can both parties gain from cooperation? Here a mis-

115. See infra text accompanying notes 160-165.

116. See Gilson \& Mnookin, supra note 59, at 380-81.

117. See supra notes $84-87$ and accompanying text.

118. See supra text accompanying notes $65-70$. 
take in evaluating the payoffs from the litigation can result in a misperception of the opposing counsel's conduct. Unremarkable behavior in a noncooperative game may be mistaken for defection in a cooperative game, with an important, albeit erroneous, effect on the lawyer's reputation for cooperation. In effect, the cost function for the lawyer's investment in reputation has an unusual error term: the more complex the legal environment, the more likely that one's investment in reputation will be lost regardless of one's actual behavior. From this perspective, the pre-litigation game takes on special significance. Not only does a party's choice of lawyer signal whether a party wishes to cooperate, it also signals the lawyer's evaluation of whether the lawsuit has a cooperative payoff structure.

4. Legal Culture. - Anecdotal evidence suggests to us that in different communities the dominant legal culture among lawyers may be more or less supportive of a cooperative problem-solving orientation, even when the communities are otherwise alike. Levels of cooperation may well depend on socialization and the dominant legal culture in a given community, as well as on market size. In California, for example, the dominant culture among matrimonial lawyers in some communities is much more adversarial than in other communities that are much larger. ${ }^{119}$ Clearly expressed community standards of proper behavior provide a means by which individuals can, through their conduct, identify themselves as being part of the community. ${ }^{120}$ Moreover, experimental evidence suggests that such standards can help shape the tastes of individual lawyers for cooperation. ${ }^{121}$ It is a familiar result in game theory that many games have multiple equilibria; that is, a number of different stable outcomes are possible and one cannot predict which will be observed in any single game. ${ }^{122}$ Socialization within a particular legal community that favors cooperation can influence whether a cooperative outcome in fact results. Thus, patterns of cooperation or conflict in particular legal communities may be path-dependent-a self-perpetuating result of the community's randomly determined initial position. ${ }^{123}$ Renewed emphasis on inculcating cooperative attitudes through legal education-perhaps through a re-

119. See Field Notes from Weekend Retreat, in Field Notes, supra note 95, at 45 .

120. See Kai T. Erikson, Wayward Puritans: A Study in the Sociology of Deviance 12-14 (1966) (function of criminal law less deterrence than allowing individuals to join community through proper conduct).

121. A recent analysis of the effect of economics training on how students played prisoner's dilemma games demonstrates the point in precisely our context. Undergraduate economics majors played cooperatively significantly less frequently than students who were not economics majors. Even more telling, cooperation among noneconomics majors increased substantially over their college careers. This trend toward cooperation was absent among economics majors. See Robert H. Frank et al., Does Studying Economics Inhibit Cooperation?, J. Econ. Persp., Spring 1993, at 159.

122. See David M. Kreps, Game Theory and Economic Modelling 95-99 (1991).

123. For an argument that retrospection, social convention, history, and culture may offer game theory a means of responding to the problem of too many equilibria, see id. at $150-85$. 
vitalization of the study of the legal profession-has much to commend it. ${ }^{124}$

\section{Facilitating Cooperation}

We have suggested through application of the prisoner's dilemma heuristic that in many circumstances lawyers may help clients achieve cooperation when the clients cannot do so themselves. In this account the relationship between the lawyers is critical. The game theory-agency theory dialectic, in turn, highlights the barriers to lawyers credibly committing their clients to cooperation. We now take up some of the normative implications of our analysis: What institutional reforms hold promise for reducing the barriers to lawyers facilitating cooperation between their clients?

We consider three levels of reform proposals. First, we survey norms of professional conduct to determine whether the governing rules create space for cooperative practice-can a reputation for cooperation be established and maintained if litigation requires zealous advocacy? Next, we consider strategies for overcoming the barriers law firms face in developing reputations for providing cooperative services. Here the hope is to provide a counterweight to the increasingly adversarial nature of commercial litigation. Finally, we consider how professional organizations can facilitate the development of more efficient cooperative reputational markets: by clarifying what constitutes cooperation and defection; by developing a sense of community and shared norms; and by developing through certification a means to increase repeat play and sanction defection.

\section{A. Cooperation and the Norms of Professional Conduct}

Traditional norms of professional conduct are insistently clientcentered. As in other professional relationships, the lawyer's technical skills and regulatory monopoly provide both a means to advance the client's interest in a specialized environment and a facade behind which the lawyer can favor herself at the client's expense. ${ }^{125}$ Professional responsibility, like other forms of fiduciary obligation, seeks to disarm that con-

124. Game theory suggests that cooperation can be sustained even in a prisoner's dilemma of a finite number of rounds provided that players believe there are some persons in the population who are socialized to play cooperatively. See Kreps et al., supra note 34, at 251. In that event, even instinctual gladiators would be best off cooperating. Socialization for cooperation serves to provide the critical mass of cooperators necessary for a stable cooperative equilibrium. The analysis of Kreps and his colleagues suggests that cooperative traits should be rewarded because they have a public goods aspect. So long as enough cooperators are believed to be present in the community, it will be in the interests of even noncooperators to cooperate and all will be better off.

125. Kenneth Arrow first stressed the centrality of information asymmetry in analyzing the market for professional services. See Kenneth J. Arrow, Uncertainty and the Welfare Economics of Medical Care, 53 Am. Econ. Rev. 941, 951 (1963). 
flict by imposing a duty of loyalty that privileges the client's interest over that of the lawyer. ${ }^{126}$ In the litigation context, the client's preferred position is given shape through the norm of zealous advocacy: the lawyer must vigorously assert the client's interests; ${ }^{127}$ the final authority on important issues of strategy rests with the client; ${ }^{128}$ and the client may discharge his lawyer at will, but the lawyer has only limited ability to withdraw from representation. ${ }^{129}$ To paraphrase the punch line of a particularly unpleasant lawyer joke, there are few things that a lawyer can decline to do.

This picture of client-centered advocacy presents a serious problem for the lawyer seeking to establish or maintain a reputation for cooperation. The zealous advocacy model views litigation from the client's perspective: as a one-round game. But in establishing and maintaining the reputation necessary to facilitate cooperation between clients, a lawyer necessarily plays a multi-round game for different clients. The lawyer may have to forgo litigation tactics that are both lawful and in the client's best interest in a particular lawsuit to allow the lawyer effectively to commit other clients to cooperate in other lawsuits. More concretely, if the payoff structure in a lawsuit takes the form of a prisoner's dilemma, the lawyer may best serve the client's interests by mid-stream defection, even though the lawyer thereby destroys her privately and socially valuable reputation for cooperation. Is zealous advocacy therefore inconsistent with reputation-based cooperation? Can a lawyer decline to defect even if defection is otherwise lawful? Can she withdraw if the client insists on defection? Can the lawyer and client agree at the outset of the representation that the lawyer will adopt a cooperative rather than a zealous advocacy litigation style? Each of these questions raises important issues of professional responsibility. Our goal here is not to resolve those issues-we leave that task to another round-but to highlight the potential of professional norms to be a barrier to commitments to cooperate.

To see the impact of professional rules of conduct, suppose that in the pre-litigation game a client and her opponent both choose lawyers with reputations for cooperation. The client disturbs the cooperative equilibrium, however, by a subsequent decision to defect at a crucial stage in the litigation. For example, the two lawyers may be engaged in voluntary information exchange rather than adversarial formal discovery, with the implicit understanding that material information will not be withheld. The client then instructs its lawyer to withhold an important document. If the other side discovers the defection the lawyer predict-

126. See Model Rules of Professional Conduct Rule 1.7 (1983) [hereinafter Model Rules]; Model Code of Professional Responsibility DR 5-101(A) (1981) [hereinafter Model Code]; California Rules of Professional Conduct Rule 3-310 (1988); Restatement (Third) of the Law Governing Lawyers $\S 201$ (Tent. Draft No. 4, 1991).

127. See infra notes $133-134$ and accompanying text.

128. See infra note 130 and accompanying text.

129. See infra notes $135-145$ and accompanying text. 
ably loses her reputation for cooperation. What can the lawyer do within the limits of the rules of professional conduct to save her reputation? Keep in mind that if the answer is nothing, more is lost than just the particular lawyer's reputation. Because the client's initial selection of a cooperative lawyer will no longer bind the client to a cooperative strategy, the parties can no longer reach a cooperative equilibrium. The cooperative lawyer has three possible responses, each of which poses a significant issue of professional conduct.

Most directly, the lawyer simply might decline to follow the client's instruction. The client is then put to a choice: either continue with the cooperative strategy or discharge the lawyer. Either outcome would protect the lawyer's cooperative reputation. This happy outcome, however, poses significant problems of professional responsibility. So long as the client's direction is not illegal, there is substantial support for the proposition that the choice of strategy belongs exclusively to the client. ${ }^{130}$

130. Ethical Consideration 7-8 of the Model Code states that "[i]n the final analysis, however, the lawyer should always remember that the decision whether to forego legally available objectives or methods because of non-legal factors is ultimately for the client and not for himself." Model Code, supra note 126, EC 7-8. Disciplinary Rule 7-101(A)(1) provides that a lawyer "shall not intentionally ... [f] ail to seek the lawful objectives of his client through reasonably available means permitted by law. ... A lawyer does not violate this Disciplinary Rule, however, by . . . avoiding offensive tactics . ...” Model Code, supra note 126, DR 7-101(A)(1). The qualification concerning offensive tactics would not apply here since the conduct involved is objectionable only to a cooperative lawyer.

The Model Rules expand the lawyer's role by distinguishing between objectives and the means used to achieve them. Ethical Consideration 7-8 leaves to the client the ultimate choice about objectives and methods. See Model Code, supra note 126, EC 7-8. Model Rule 1.2(a), in contrast, distinguishes between objectives and means: "A lawyer shall abide by a client's decisions concerning the objectives of representation ... and shall consult with the client as to the means by which they are to be pursued." Model Rules, supra note 126, Rule 1.2(a). The comment to the Rule does not indicate what happens when, after consultation, the lawyer and client disagree about the means. If the answer is that the lawyer can then seek to withdraw, analysis shifts to the standards governing withdrawal, considered infra text accompanying notes 137-138.

The extent to which Rule 1.2(a) differs from the Code depends on the distinction between objectives and means. If the distinction turns on whether the choice of means has an important impact on achieving the objectives, the distinction collapses. The Reporter for the Model Rules seems to have taken this view: "[T] he client has [the] authority to instruct the lawyer what course of action to pursue, so long as the course of action is within the limits of the law." Geoffrey C. Hazard, Jr., My Station as a Lawyer, 6 Ga. St. U. L. Rev. 1, 4-5 (1989). In all events, the comment to Rule 1.2(a) acknowledges that "[a] clear distinction between objectives and means . . cannot be drawn." Model Rules, supra note 126, Rule 1.2 (a) cmt. Thus, even the less client-centered Model Rules leave ambiguous the lawyer's ability to protect a cooperative reputation by declining to defect.

The American Law Institute's Restatement of the Law Governing Lawyers comes down hard on the side of the client on this issue. Section 32 provides that "[a] client may instruct a lawyer during the representation. Such an instruction binds the lawyer if consistent with ... other provisions of this Restatement and any valid existing agreement between client and lawyer." Restatement (Third) of the Law Governing Lawyers § 32(2) (Tent. Draft No. 5 , 1992) [hereinafter Restatement]. The comment to section 32 is even more explicit: "A client may give instructions to a lawyer during the representation about matters within the 
Thus, the client's instruction to defect puts the lawyer, not the client, to a choice: obeisance or withdrawal. However, withdrawal is available only if the circumstances satisfy the preconditions to the ethical termination of the representation. ${ }^{131}$ This shift in the locus of the decision is crucial because the client's right to discharge the lawyer is unqualified while the lawyer's right to withdraw is significantly restricted. The lawyer cannot avoid these restrictions by forcing the client to choose between following the cooperative strategy and discharging her.

A less drastic response by the lawyer would also save her reputation; however, it is also problematic under professional responsibility rules. The potential for defection results from the lawyer's reputation for cooperation. Her very retention implicitly represents that she will not behave strategically in exchanging voluntary disclosures. Only because the other counsel relies on the implicit representation can defection benefit the client and damage the reputation of the cooperating lawyer. In this situation, the lawyer can protect her reputation while still following the letter, if not the spirit, of the client's directions by generally disclosing to opposing counsel that continued reliance on the lawyer's reputation in this case would not be appropriate. For example, one lawyer who found himself in this situation recounted that he dealt with the problem by simply saying "en garde" to opposing counsel. ${ }^{132}$ The message imbedded in the phrase was that opposing counsel should protect himself, that cooperative rules did not apply, and that subsequent adversarial behavior, because not unexpected, would not be a reputational breach.

Here again, however, the lawyer's effort to preserve his reputation poses issues of professional conduct. As we have seen, the client has a strong claim to the ultimate authority on issues of strategy. ${ }^{133}$ Moreover, a lawyer is obliged to protect a client's confidences. ${ }^{134}$ The lawyer's clever disclosure of the new rules of engagement, which renders the strategy, and the client's authority, less effective, plausibly conflicts with the professional norms that allocate strategic discretion to the client and that create the lawyer's obligation to maintain client confidences.

That leaves the lawyer with but a single response in the face of client direction to defect-withdrawal. But it is not clear that the ethical norms

lawyer's reasonable power to perform, just as any other principal may instruct an agent." Id. $\$ 32 \mathrm{cmt}$. d. No distinction is drawn between objectives and methods.

131. The rules governing withdrawal are taken up infra notes 135-145 and accompanying text.

132. See Field Notes from Winter Retreat, in Field Notes, supra note 95, at 45.

133. See supra note 130 and accompanying text.

134. On this issue the Model Code, Model Rules, and the Restatement do not materially differ. See Model Code, supra note 126, DR 4-101(A) (A lawyer cannot reveal "information gained in the professional relationship that the client has requested to be held inviolate or the disclosure of which would be ... detrimental to the client."); Model Rules, supra note 126, Rule 1.6(a) ("A lawyer shall not reveal information relating to representation of a client unless the client consents after consultation ...."); Restatement, supra note $130, \S 28(3)$ (“[A lawyer must] . . s safeguard the client's confidences . . .."). 
allow withdrawal under these circumstances. Under the Model Code of Professional Responsibility (Model Code), a lawyer can withdraw from representation in this situation only if the client "[i]nsists that the lawyer pursue a course of conduct that is illegal or that is prohibited under the Disciplinary Rules."135 The Model Rules of Professional Conduct (Model Rules) generally provide the lawyer with a broader withdrawal right, but there is substantial ambiguity concerning its application in our circumstance. Model Rule 1.16(b) (3) allows the lawyer to withdraw, even if doing so has a material adverse effect on the client, if "a client insists upon pursuing an objective that the lawyer considers repugnant or imprudent."136 The Model Rules, however, distinguish between objectives and means. ${ }^{137}$ Our situation clearly concerns a strategy-a means not an objective. Thus, the Model Rule would also not allow withdrawal. ${ }^{38}$

The American Law Institute's recent Restatement of the Law Governing Lawyers (ALI Restatement) may relax the standards enough to be helpful. In its current version, section 44 allows a lawyer to withdraw if the client directs the lawyer to take action that the lawyer believes to be "repugnant or imprudent" 139 even if the ordered action is legal. ${ }^{140}$ The

135. Model Code, supra note 126, DR 2-110(C)(1)(c).

136. Model Rules, supra note 126, Rule 1.6(b) (3).

137. See supra note 130 .

138. We recognize that our interpretation of Model Rule 1.2 and Model Rule 1.16 may be seen as inconsistent, but the confusion results in substantial part from the Model Rules' general ambiguity with respect to allocation of authority between client and lawyer. Under Rule 1.2(a), the client sets the objectives of litigation, but the means are determined by consultation with the lawyer without revealing what happens if the lawyer and client disagree. See supra note 130. We argued with respect to Rule 1.2 that a choice of means that substantially effects attainment of the client's objective amounts to an objective, which puts the matter under the sole authority of the client. This interpretation is troublesome under Rule 1.16 because a lawyer can withdraw despite prejudice to the client if the lawyer disagrees with an objective, and we have treated the matter as an objective with respect to Rule 1.2. In defense of our interpretation, the two Rules seem to be about different issues. Rule 1.2 concerns allocation of authority between lawyer and client-decision-making power not morality. Rule 1.16 seems to be about morality: the lawyer should not be required to pursue an objective that he finds morally repugnant; means that are not illegal in themselves and are undertaken in pursuit of a benign objective do not rise to that level. The problem may well be that the American Bar Association could not reach consensus on the proper allocation of authority and, as is not infrequent in law reform projects that require a membership vote, simply fudged it. If Rule 1.16 is read to give the lawyer the right to withdraw if the client insists on means that the lawyer dislikes, then the Model Rules structure could have been substantially simplified by assigning sole authority over means to the lawyer and allowing the client to exercise the client's unrestricted withdrawal right if the client wanted to pursue a strategy the lawyer disliked.

139. Restatement, supra note $130, \S 44$. Note that section 44 does not distinguish between objectives and means as does the Model Rules. Perhaps this is because Restatement section 32 explicitly resolves the authority issue in favor of the client. See supra note 130.

140. If the action directed by the client is illegal or violates a disciplinary rule, $\S 44$ (2) (a) requires that the lawyer withdraw. See Restatement, supra note 130, $\$ 44$ (2) (a). Similarly, $\S 44(3)$ (d) allows withdrawal if the lawyer's actions would be used for a 
question then is what those terms mean. The commentary states that more than disagreement with the client is necessary; the action directed by the client must be "so harmful to the client or others that the lawyer cannot in good conscience ... assist in its pursuit." ${ }^{141}$ Examples in the comment suggest some elasticity to the concept. According to the Restatement, enforcing "a landlord client's [lawful] right to evict a poor tenant without cause," 142 or validly asserting "the statute of limitations against a just claim" ${ }^{143}$ cross the threshold. ${ }^{144}$ Moreover, the rule is intended to protect "the interest of lawyers in maintaining their integrity and personal and professional reputations." 145

Withdrawal thus provides the cooperative lawyer's best course of action in the face of a client's instruction to defect, but the lawyer's position is strongest with respect to the purely advisory ALI Restatement and more problematic with respect to the often obligatory Model Code or Model Rules. The risk that the lawyer cannot withdraw to avoid defection presents a serious barrier to reputation formation and, ultimately, a threat to the stability of a pre-litigation game cooperative equilibrium. If the client's selection of a cooperative lawyer is not a credible commitment to cooperate, then the lawyer-mediated solution to the litigation prisoner's dilemma unravels.

Both the difficulty in withdrawing after a client instructs the cooperative lawyer to defect and the importance of the pre-litigation game to a

fraudulent purpose. See id. $\S 44(3)$ (d). The sections may not parse quite so neatly if the lawyer is not certain that the action is illegal. How much risk must the lawyer take in furthering the client's goals? Of course, if the lawyer can withdraw when only a possibility of illegality exists, the advocacy skills of a lawyer desiring to withdraw are then brought to bear against the client, a paradoxical outcome at best.

141. Id. $\S 44 \mathrm{cmt}$. $\mathrm{h}$.

142. Id. Because the lawyer can withdraw if the client's eviction action would be frivolous-i.e., the client lacked the right to evict the tenant without cause-the example is at least plausibly read to allow the lawyer to withdraw even if the client had clear authority under the lease to terminate the tenancy. See Monroe Freedman, ALI to Clients: Drop Dead!, Legal Times, May 31, 1993, at 26, 30.

143. Restatement, supra note $130, \S 44 \mathrm{cmt}$. h.

144. Monroe Freedman reports an interpretation of repugnancy even more favorable to the cooperative lawyer who wants to withdraw rather than defect. In response to a question by Freedman concerning the breadth of the lawyer's withdrawal right, Associate Reporter John Leubsdorf (under ALI procedures at least the initial drafter of the language) is said to have stated that the right would cover a situation where the lawyer disagreed with a client's direction to seek to recuse a judge. See Freedman, supra note 142, at 30. Since it is fair to assume that the lawyer's self-interest in her reputation-it may not be good for the lawyer's career to move to recuse a local judge-at least in part animates the desire to withdraw (together, to be sure, with a concern for the efficient administration of justice), the cooperative lawyer's similar concern for her reputation (and the social value of facilitating cooperation) would also seem to be covered. As one of the author's experience with ALI procedures instructs, however, one must be hesitant in relying on a Reporter's colloquy in an annual meeting as authoritative legislative history concerning the interpretation of an ALI product. In the end, the black letter and commentary stand on their adoption by the ALI membership.

145. Restatement, supra note $130, \S 44 \mathrm{cmt}$. h. 
cooperative equilibrium suggest the importance of timing. We need to look for a solution to the defection problem in the period before the prelitigation game begins, rather than after defection is directed. A central feature of the Model Rules is the client's power to reject zealous advocacy in favor of a different model of representation. For example, in a counseling setting, Model Rule 2.2 expressly contemplates that a client may elect an intermediary rather than an advocate, or joint transactional representation rather than separate distributional bargaining. Like joint transactional representation, a client should also have the opportunity at the outset to select a cooperative rather than a gladiatorial strategy. This outcome requires an initial commitment by the client that it will not direct the cooperative lawyer to defect. The outcome follows implicitly from the logic of the client's choice, and should follow explicitly from the terms of the cooperative lawyer's engagement.

This analysis suggests an obvious strategy for removing the professional responsibility barrier to the use of reputation to facilitate cooperation. A clear statement that the Model Rules contemplate a client's selection of a cooperative strategy, supported by the client's agreement at the time of retention to an unrestricted right of withdrawal if the lawyer subsequently disagrees with the client's strategic choices, would eliminate that barrier. Moreover, it would do so without conflict with the principal of client autonomy that animates present restrictions on a lawyer's freedom to disregard a client's strategic decision or to withdraw. Only if the rules allow the client to "tie its hands" at the time of the lawyer's engagement-to give the cooperative lawyer the right to withdraw rather than defect later in the litigation-can the client credibly commit to cooperate. Enhancing the cooperative lawyer's ability to protect her investment in reputation expands rather than restricts the client's control over how the lawyer conducts the client's litigation. ${ }^{146}$

We should mention one last problem. So far we have considered the problem of the cooperative lawyer whose client asks him to defect first. What if the other side defects first? Can a cooperative lawyer refuse to play tit-for-tat? A tit-for-tat strategy, as we suggested earlier, may not be an effective way to establish and maintain a reputation for cooperation if it is difficult to demonstrate to the legal community which side defected first. On the other hand, it would seriously jeopardize an "innocent" client's interests in future rounds if his lawyer could never retaliate or engage in those tactics necessary to protect the client in the future. The best solu-

146. Henry Hansmann and Reinier Kraakman nicely develop how restricting one's options ex ante expands them ex post in Henry Hansmann \& Reinier Kraakman, HandsTying Contracts: Book Publishing, Venture Capital Financing, and Secured Debt, 8 J.L. Econ. \& Org. 628 (1992).

The ALI Restatement provides support for this approach in $\S 32$ by inviting the lawyer and client to allocate authority between them by contracts. See Restatement, supra note $130, \S 32$. The Restatement is inexplicably silent, however, with respect to agreements that restrict or expand the lawyer's ability to withdraw under $\S 44$. 
tion, for both the client and the cooperative lawyer, would be for the lawyer to help find a gladiator whom the client might either substitute in the case or associate with the cooperative counsel.

\section{B. Can Law Firms Develop Reputations for Providing Cooperative Services?}

A striking characteristic of large commercial litigation is the absence of reputational differentiation with respect to attitudes toward cooperation among the dominant law firms. This stands in stark contrast, for example, to family law practice in which lawyers, not firms, develop reasonably clear reputations as cooperators or gladiators. The analysis in Part III.A.2 explains why: too much noise. Law firms may include both cooperators and gladiators, and have practices that include cases in which there might be gains from cooperation and other cases in which the dominant strategy is gladiatorial. Even if large firm lawyers play tit-for-tat, mistaken evaluation of the lawyer's conduct or the character of the case will result in cycles of mutual defection. The overall cacophony inhibits the development of cooperative reputations for a firm as a whole.

Our analysis suggests two strategies through which law firms might develop reputations for cooperation, each of which involves noise reduction through specialization. One strategy envisions creating a boutique that only furnishes cooperative representation. The second contemplates a specialized cooperative department within a large firm. The two strategies have different advantages and drawbacks; in the end, each may be best suited to different segments of the profession. The boutique strategy is designed for lawyers forming new firms; the specialized department strategy is directed at existing large firms.

1. The Cooperative Boutique. - Imagine a law firm that limits its practice to cooperative representation. The firm specializes in alternative dispute resolution, conducts litigation in a problem-solving manner, and declines cases in which the client wishes to engage in thermonuclear litigation. The firm's goal is to develop a reputation for cooperation that allows its clients credibly to commit to cooperate by retaining the firm, and to receive a share of the value added by its role in overcoming the client's prisoner's dilemma.

Because the portion of the legal community engaged in commercial litigation is large, these lawyers must develop reputations indirectly rather than experientially, by adhering ${ }^{147}$ to a cooperative practice style that prospective clients and other lawyers can observe by means other than actual litigation experience with the firm. This approach centers on making investments visible to the legal and client community whose value will dissipate should the cooperative boutique turn gladiator. ${ }^{148}$ For exam-

147. Cf. Oliver E. Williamson, Credible Commitments: Using Hostages to Support Exchange, 73 Am. Econ. Rev. 519, 528-29 (1983) (discussing the use of a "hostage" to make a credible commitment in a large market).

148. See Klein \& Leffler, supra note 43 , at 626-27. 
ple, image advertising substitutes for direct experience as a way of learning about the firm's style. Turning away noncooperative work, and thereby putting all of the firm's eggs in a single basket, makes the advertising credible.

While a boutique strategy allows the firm to make investments in a firm-specific reputation for cooperation, it nonetheless poses two problems for clients who seek to demonstrate to their opponents their desire to cooperate by their choice of lawyer. The first problem concerns the way the boutique firm plays the pre-litigation game. Recall that the client may lack the skills necessary to determine whether the opposing party's lawyer is a cooperator or a gladiator. At this stage, the client must rely on the cooperative firm to identify the opposing counsel's type, and to withdraw in favor of a gladiator if counsel recognizes the opposing counsel as a gladiator. ${ }^{149}$ But precisely because the client must rely on its lawyer to withdraw in the event of a mismatch, the cooperative boutique has a conflict of interest. Correctly identifying opposing counsel as a gladiator results in the loss of the business; because we have presumed that the client is unable to itself observe the opposing counsel's type, the client cannot tell ex ante whether the boutique is truthfully disclosing opposing counsel's type. ${ }^{150}$ The boutique then can retain the client by mislabeling a gladiator as a cooperator. Thus, the client's inability to identify self-interested behavior by the cooperative boutique during the pre-litigation game threatens to cause the boutique strategy to unravel: if the client cannot rely on the boutique in the pre-litigation game, the client cannot risk the sucker's payment by retaining it to commit credibly to a cooperative strategy.

The problem dissipates, however, because the legal community can eliminate the gains from strategic manipulation of the pre-litigation game, even if the client cannot directly observe opposing counsel's type, so long as the outcome of the litigation itself discloses the manipulation ex post. Manipulation of the pre-litigation game results in the boutique's client suffering the worst outcome: the sucker's payoff when the other side hires a gladiator. Surely a client can recognize the worst outcome, with the result that the boutique's deception is then apparent to the client and its investment in reputation is lost. As a result, strategic manipulation of the pre-litigation game is not an effective strategy for the boutique.

The second problem concerns manipulation of the pre-litigation game not by the cooperative boutique, but by opposing counsel. Suppose that opposing counsel lacks a clear-cut reputation but represents her intention to cooperate. In that event, our analysis does not require that the boutique withdraw, but a risk remains that opposing counsel's cooperative posture is strategic and that she intends a midstream defection at

149. See supra text accompanying notes $51-53$.

150. See supra note 40 . 
a time when withdrawal by the boutique would be expensive to the client both in additional fees and in strategic disadvantage. Should such defection occur, the dilemma is how to protect the client by responsively providing the client a gladiator without risking the cooperative reputation of the boutique.

Again, there appears to be a viable solution to the problem of strategic manipulation of the pre-litigation game. To be sure, the boutique could provide gladiatorial services itself. However, doing so runs the dual risk that the boutique's lack of specialized adversarial skills will disadvantage the client and that the legal community will misperceive the boutique's shift to gladiatorial tactics as a defection, at the expense of the boutique's reputation. Both these risks can be minimized if the boutique responds to a midstream defection by associating another firm to act as gladiator. This reduces the additional expense to the client (because the boutique can still provide those services with respect to which its caserelated knowledge would be most costly for the new firm to duplicate), while still assuring the client of specialized gladiatorial services. And because the boutique has associated another firm to be the gladiator, the legal community is less likely to mistake its behavior for defection. Because the boutique does not provide the gladiatorial services itself, it receives no fees from the increased combativeness. The strategy thus eliminates the potential conflict of interest that would otherwise exist if the boutique both claimed that opposing counsel defected and took up the mantle (and revenues) of a gladiator. By diverting those fees to a third party, the boutique reduces its expected fees from the case, thereby rendering its claim of defection by opposing counsel credible. ${ }^{151}$

2. The Specialized Law Firm Department. - Existing firms that already possess a mixed reputation cannot, of course, follow a boutique strategy. For such firms, the parallel strategy is to create a specialized cooperative department within the existing firm. All of the advantages associated

151. The analysis of the boutique firm's strategy in the face of opposing counsel's midstream defection parallels a similar role that solicitors might have played in the British system before solicitors were given access to the courts. Until recently, only barristers were allowed to advocate in court. However, solicitors conducted all pre-trial investigation and negotiation, and were responsible for selecting a barrister should the case go to trial. See, e.g., Toran, supra note 81 , at 313 . Because the solicitor chose the barrister to represent his client in court, " $[t]$ he livelihood of a barrister [was] thus wholly dependent upon solicitors and what they [thought] of him." Megarry, supra note 81, at 397. The risk that the solicitor might choose a "gladiator" barrister, as well as the increased legal fees involved in hiring a barrister, created a strong incentive to settle before the barrister was brought in.

On the respective roles of barristers and solicitors under the former system, see generally Geoffrey P. Wilson, Cases and Materials on the English Legal System 116 (1973); Peter Webster, The Bar of England and Wales: Past, Present and Future, in Legal Institutions Today: English and American Approaches Compared 84, 96-97 (Harry W. Jones ed., 1977). Solicitors can plausibly commit to behave cooperatively in negotiating the pre-litigation resolution of a dispute because defection-in this context strategic bargaining that increases the likelihood of litigation-results in the matter's referral to an unrelated barrister. 
with a specialized boutique are available with a specialized law firm department. In fact, the specialized department has certain added benefits. Because this strategy contemplates an internal referral-transfer of the case to one of the firm's adversarial litigators-if the opposing client chooses a gladiator in the pre-litigation game, the cooperative department has no incentive to misidentify opposing counsel's type so as to avoid withdrawal and loss of the business. The work remains within the firm in all events.

The strategy also has an advantage in the event of midstream defection by opposing counsel. Because the referral to a gladiator is internal, it would likely entail lower transaction costs to get the new lawyer up and running. Because the firm will capture some of the efficiency gains from developing techniques to minimize transfer costs, as well as the advantages of shared computer and file systems, internal referrals may also be more effective than third party referrals when the client is forced to change litigation style.

But there are also unique costs to the specialized department strategy. The most important concern the organizational difficulties of accommodating a specialized cooperation department within the structure of a traditional law firm. First, a cooperative practice is likely to be substantially less leveraged, and therefore less profitable, than a gladiatorial litigation practice. ${ }^{152}$ Cooperative litigation likely entails much less of the type of work that can be assigned to a team of associates than does gladiatorial litigation. Cooperative litigation, for example, will involve less formal discovery and motion work-normally handled by associates. To be sure, the cooperative department can make up a portion of that difference with the premium that it can charge for the department's cooperative reputation, but we are skeptical as to whether this premium would entirely eliminate the difference. While a specialized cooperative department holds out a strong case for value billing, as opposed to hourly billing, there remains significant resistance to value billing within the legal community. ${ }^{153}$

A similar problem concerns the difficulty in allocating the benefits that the cooperative department confers on the rest of the firm. The very existence of the cooperative department may improve the firm's overall ability to attract clients because the possibility of internal referral may deter manipulation of opposing counsel's pre-litigation game. But alloca-

152. Our calculations suggest that a good deal of the variance in profitability among different firms can be explained by differences in leverage. See Ronald J. Gilson, Jr. \& Robert H. Mnookin, Coming of Age in a Corporate Law Firm: The Economics of Associate Career Patterns, 41 Stan. L. Rev. 567, 585-86 (1989).

153. Value billing sets a price for services based on the value of the services to the client rather than the cost in time to the lawyer providing them. See, e.g., Beyond the Billable Hour: An Anthology of Alternative Billing Methods (Richard C. Reed ed., 1989) (collection of essays discussing billing practice and reasons for shift to value billing); Donald S. Akins, Client Acceptance of Alternative Pricing, 15 Legal Econ., Sept. 1989, at 28, 29. 
tion of that gain among departments may be quite conflictual because, while the contribution of the department that does the work can be quantified, the existence of the cooperative department's contribution to general firm reputation is subjective both in its existence and in its measurement.

The second difficulty grows out of the first. Having departments of different profitability in a single firm creates organizational centrifugal force. A tilt in power and money toward the more profitable department breeds resentment. In a market dominated by firms that distribute profits on a productivity basis, a more egalitarian distribution may lead to the more profitable partners grabbing and leaving. ${ }^{154}$ As the continuing conflict within large accounting firms-between the more profitable consulting practice and the increasingly less profitable (and litigation prone) auditing practice- demonstrates, ${ }^{155}$ the incompatibility between cooperative and gladiatorial litigation practice may be less a problem of reputation formation than of organizational structure.

\section{Reducing Noise: The Role of Professional Organizations}

A professional organization might facilitate cooperation among its members and have a dramatic effect on the development of a reputational market. Imagine an organization that limited its membership to attorneys who specialized in cooperative representation. Such an organization might promulgate standards defining cooperative conduct and defection in various contexts. The organization might then certify an attorney as cooperative, but only after intensive screening and review: a number of existing members might have to vouch for the fact that the nominee had consistently behaved appropriately over an extended period of time and had never defected. The organization might also stand ready to impose sanctions-including suspension or expulsion-in order to maintain cooperative norms.

If such an organization existed, it would obviously enhance the reputation of its members: clients and lawyers alike would be invited to rely on the organization's claim that its members would engage only in cooperative litigation, and the organization and its members would have a powerful incentive to maintain the quality of its "stamp of approval." Although no such organization presently exists, the hypothetical provides a useful benchmark for exploring how the activities of existing professional groups and organizations for lawyers might well facilitate cooperation through reputational markets.

Some professional groups limit membership to specialists and require admission based on professional criteria. The American Academy

154. See Gilson \& Mnookin, supra note 152 (developing the effect on firm stability of different methods of profit division).

155. See Mark Stevens, The Big Six 105-54 (1991) (recounting the intra-firm conflict at Arthur Anderson \& Co.). 
of Matrimonial Lawyers is an example of this. ${ }^{156} \mathrm{~A}$ few states-California, for example-have certified attorneys as specialists in particular areas. ${ }^{157}$ Certification requires not only that they display a certain substantive knowledge, but also that they have had the requisite experience. Other groups consist primarily of specialists, but do not actually limit their membership to specialists. The various sections of the American Bar Association and some state and local bars are examples; these are typically open to anyone prepared to pay the dues, although their activities are directed at specialists. Bar associations are often organized on a geographical basis: cities, counties, and states all typically have their own bar associations and the state bar often has power to impose sanctions for violations of professional standards of conduct.

Organizational links between opposing counsel hardly assure cooperation even when membership is limited to experienced specialists. As we have indicated, the American Academy of Matrimonial Lawyers does not limit its membership to cooperative problem-solvers; gladiators are members as well. ${ }^{158}$ Nevertheless, organizations can facilitate the operation of reputational markets. One consequence of membership, with or without certification, is that it may increase the opportunities for repeat play within the group; litigation styles thereby become more directly observable. It may also make it easier and cheaper to impose informal sanctions for defection through gossip and reputational damage than would be true in a more atomistic world.

A second very important way that professional organizations can facilitate cooperation is by clarifying norms. In a prisoner's dilemma model, the parties either cooperate or defect, and the meaning of each move is clear. The real world is noisy: it may not be at all clear what types of behavior entail cooperation, or what moves constitute defection. One useful role for professional organizations is to clarify what cooperation or defection means in the context of particular kinds of disputes. Defining the rules and norms of cooperative play can be beneficial in a number of ways. Most fundamentally, it provides guidance as to what the legal community expects of a lawyer who wishes to make a cooperative move and

156. The Academy's rules for membership include the following: To become a member of the Academy, a candidate must be invited to apply by two active members. Candidates must have been practicing for at least ten years and have concentrated at least seventy-five percent of their practice in matrimonial law. Candidates from states where there is certification must be certified as family law specialists. Information about each candidate's expertise and ethics is solicited from judges and other lawyers from the area in which the candidate practices. The candidate must be interviewed, pass a rigorous examination on the practice of matrimonial law, and "demonstrate the highest standing in his or her legal community for character and ethical practice." See American Academy of Matrimonial Lawyers Standards of Admission (Nov. 6, 1987) (on file with the Columbia Law Review).

157. See Cal. Prof. Rules Legal Specialists $§ \S 1-6$ (West Supp. 1993); see also New Standards Set for Certification and Recertification of Legal Specialists, 50 Cal. St. B.J. 309 (1975) (reviewing new standards for certification and recertification as specialists).

158. See supra note 97 . 
develop over time a reputation for cooperation. As Robert Frank has pointed out, even in circumstances when defection may not be observable, much less verifiable, some lawyers will want to conform their behavior to cooperative norms-because of how they define themselves. ${ }^{159}$ As a second advantage, definition of norms reduces noise by making conduct more observable. If the community develops a sense of shared norms, then it is easier for counsel to observe whether the conduct of the opposing lawyer conforms to those norms.

We suspect that the meaning of cooperation and defection might appropriately vary by context. One important task of a professional group consisting of specialists would be to develop, in particular areas, the requirements of cooperative or problem-solving representation and to identify what these requirements imply for the relationship between the lawyers. The work of the American Academy of Matrimonial Lawyers provides a useful model. In 1992, the Academy promulgated standards of conduct to "establish bounds of advocacy," and to describe ethical and professional behavior in matrimonial disputes that facilitated cooperative representation. ${ }^{160}$ These standards of conduct provide a very useful set of focal points to define cooperation in family law practice.

The standards require that opposing counsel "should cooperate in exchange of information and documents whenever possible," should not use discovery for "delay or harassment," should not engage in "obstructionist tactics," 161 and that counsel should not attempt to gain an advantage by "delay" in the service of pleadings or correspondence. ${ }^{162}$

Professor Robert Aronson, the reporter for the standards, indicated that the Academy undertook the project in part because of concerns that there appeared to be an "increased prevalence of rudeness and hardball tactics" in matrimonial disputes. ${ }^{163}$

Academy members believed the [Rules of Professional Conduct] to provide insufficient guidance or regulation with respect to "Bombers" who engage in "hardball" or "Rambo" tactics in an effort to wear down the opponent. Those lawyers who believe that "scorched earth" tactics are the key to success in matrimonial litigation justify their "win at any cost" behavior on the basis of zealous advocacy on the client's behalf. In some cases this approach intimidates or wears down the opponent, resulting in victory for the offensively aggressive (and aggressively offensive) lawyer. More often, however, such tactics simply cause

159. See Frank, supra note 45, at 11-19, 91-92 (suggesting that individuals are often motivated to behave morally or cooperatively because of their emotional predispositions or "character" rather than rational self-interest).

160. See The Bounds of Advocacy: American Academy of Matrimonial Lawyers Standards of Conduct, reprinted in $9 \mathrm{~J}$. Am. Acad. Matrim. Law. 1, 2 (1992) [hereinafter AAML Standards].

161. AAML Standards, supra note 160, Standard 3.6.

162. See AAML Standards, supra note 160, Standard 3.12.

163. Aronson, supra note 9 , at 53 . 
delay and divisiveness, increase expense, and waste judicial resources. Enlightened lawyers hold the view that courteous behavior is not a sign of weakness, but is consistent with forceful and effective advocacy. The spirit of cooperation and civility does not simply foster collegiality of the Bar, although that is certainly a welcome side effect, but also promotes justice and efficiency in our legal system. The general public, as well as clients, have a right to expect and demand a high standard of conduct by lawyers. ${ }^{164}$

One commentator suggested that these standards for matrimonial practice provided workable guidelines for "adversarial cooperation":

Adversarial cooperation is cooperative competition. These terms mean lawyers working together to create an environment in which information is readily exchanged; legal and factual issues are discussed and either resolved or simplified then highlighted for presentation to the court; logistical problems of discovery, depositions, hearings and trial are handled in a nonconfrontational way between counsel and their staffs; and both sides make every attempt to move the case to resolution as simply, expeditiously and cost-efficiently as is reasonably possible . . . .165

\section{ConClusion}

Our story weaves together three principal ideas: (a) the prisoner's dilemma offers a suggestive and powerful metaphor for some aspects of litigation; (b) a lawyer's reputation may serve to bond a client's cooperation in the litigation process, thereby resolving the prisoner's dilemma; and (c) principal-agent conflicts (whether between lawyers and clients, or between lawyers and their firms) create incentives that sometimes facilitate cooperation in litigation but that, at other times, undermine cooperation. Our message is that the relationship between opposing lawyers and their capacity to establish credible reputations for cooperation have profound implications for dispute resolution: if the payoff structure establishes cooperation as the most desirable strategy and supportive institutional structures exist, lawyers may be able to damp conflict, reduce transaction costs, and facilitate dispute resolution.

Our story rests fundamentally on the idea that lawyers develop reputations, and that the reputation for being a cooperative problem-solver may be a valuable asset. When opposing lawyers know and trust each other, we believe there often will be substantial opportunities for both parties to benefit by reducing transaction costs. Our analysis, however, is limited by the absence of data. To be sure, we offer examples of professional settings - commercial litigation and family law practice-where be-

164. Id. at 52-53 (footnotes omitted).

165. Stephen W. Sessums, Adversarial Cooperation: A Concept That Works, 9 J. Am. Acad. Matrim. Law. 61, 62 (1992). 
havior is consistent with our framework. But further empirical research, devoted to understanding what lawyers really do, might usefully explore a variety of empirical questions relating to the idea of reputational markets for lawyers.

A very basic question goes to how lawyers actually cooperate in the litigation process. How do lawyers signal their willingness to cooperate? To what extent is a lawyer's reputation important in facilitating cooperation? In different practice settings, is there actually a consensus about a lawyer's reputation? How do these reputations develop? In choosing lawyers, how do clients secure information about the reputation of their own lawyer?

Theory suggests that a reputational market would operate most effectively when the size of the legal community is comparatively small. The actions of lawyers can then be well publicized, and lawyers can expect to face each other repeatedly in the future. Thus our analysis at least suggests why small-town lawyers may be less prone to exacerbate disputes with one another than are big-city lawyers, and also why one might expect to see a greater degree of cooperation within certain specialties than within the general community of attorneys. These questions suggest opportunities for empirical research to see whether there are significant differences among the levels of cooperation in various communities, and to what extent one can explain these differences by the existence (or nonexistence) of reputation markets.

Our analysis suggests that the level of noise-both about the character of a lawyer's behavior and the character of the litigation-is central to reputation formation. Empirical research would be helpful concerning whether cooperation or defection can be more clearly characterized in some practice areas, and whether the extent of consensus over a lawyer's reputation varies with clarity. For example, our own experience suggests broad consensus concerning lawyers' reputations in labor practice. Does this correspond with greater clarity of litigation and tactics?

Evidence concerning how the reputations of lawyers and law firms spread through a community would also be interesting. We would expect more cooperative behavior in areas of litigation in which both sides can observe and confidently characterize the behavior of opposing counsel as cooperation or defection. Indeed, in contexts in which cooperation is not only observable but verifiable to a judge, the judiciary may represent a powerful mechanism to insure cooperation. Litigators are profoundly concerned about their reputation with judges and are typically very hesitant about doing anything to damage their reputation with a judge before whom counsel is likely to appear many times in the future. But experience with Rule 11 sanctions-judicially imposed sanctions for some types of uncooperative behavior-raises serious questions concerning the verifiability of much misconduct.

We began our inquiry by asking whether lawyers facilitate dispute resolution or instead exacerbate conflict. Common sense and anecdotal 
observation together suggest that lawyers sometimes help and sometimes hurt. Our goal has been to provide a theoretical framework to understand better when conflict and cooperation occur and how we can facilitate greater cooperation. The analysis presented represents an early reconnaissance mission that suggests for ourselves (and we hope for others) the value of further exploration-both theoretical and empirical. 